\title{
Altered balance of interleukin-13/interferon- gamma contributes to lacrimal gland destruction and secretory dysfunction in CD25 knockout model of Sjögren's syndrome
}

Fang Bian, Flavia L Barbosa, Rosa M Corrales, Flavia SA Pelegrino, Eugene A Volpe, Stephen C Pflugfelder and Cintia S de Paiva

\begin{abstract}
Introduction: The lacrimal gland (LG) of the CD25\% model of Sjögren's syndrome (SS) has high interleukin (IL)-17, IL-13 and interferon-gamma (IFN- $\gamma$ ) cytokines. The specific contribution of these cytokines to the onset and severity of dacryoadenitis in the $\mathrm{CD} 25 \%$ mice has not been evaluated.

Methods: $\mathrm{CD}^{-} 5^{-} / \mathrm{IL}-17 \mathrm{~A}^{-}{ }^{\top}, \mathrm{CD} 25^{-} / \mathrm{IL}-17^{-} / \mathrm{IFN}-\gamma^{-}{ }^{-}$and $\mathrm{CD}^{-} 5^{-} / \mathrm{IFN}-\gamma^{-} /$were used at 4, 8, 12, 16 weeks (W). Total lymphocytic infiltration was evaluated by histology and characterized by flow cytometry. Epidermal growth factor (EGF) concentration was measured in tears. Immunofluorescent staining evaluated expression of IFN- $\gamma$ receptor (IFN- $\mathrm{R}$ ) and apoptosis. Real-time PCR evaluated inflammatory and T cell-related cytokines expression in LG. Caspase-3, -8, -9 activities was assayed in LG lysates. T helper cytokines were measured in serum by Luminex assay.

Results: The greatest total LG infiltration at $8 \mathrm{~W}$ was seen in $\mathrm{CD}^{-} 5^{-} /^{-} \mathrm{IL}-17 \mathrm{~A}^{-} /^{-}(95 \%)$, followed by $\mathrm{CD}^{-} 5^{-} /^{-}(71 \%)$ and $\mathrm{IL}-17^{-} \digamma^{-}(12 \%)$. Tear EGF concentration was in normal range in $\mathrm{CD} 25^{-}{ }^{-}$at $4 \mathrm{~W}$ and in very low levels in both $\mathrm{CD}^{-} 5^{-}$ and $\mathrm{CD} 25^{-} /^{-} \mathrm{IL}-17 \mathrm{~A}^{-} I^{-}$. CD25 $\digamma^{-}$had high levels of inflammatory cytokines transcripts in $\mathrm{LG}$ compared to $\mathrm{IL}-17^{-} /^{-}$mice;

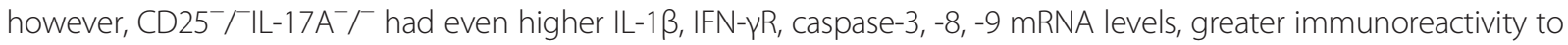
IFN- $\gamma R$ in $L G$ acini, greater number of apoptotic ${ }^{+}$cells and greater caspases activities in the $L G$ at $8 \mathrm{~W} . \mathrm{CD}_{2} 5^{-} / \mathrm{IL}^{-}-17 \mathrm{~A}^{-}$/ had lower IL-13 concentration and lower IL-13/IFN- $\gamma$ ratio compared to CD25 $\digamma^{-}$in serum. $\mathrm{CD}^{-} 5^{-} / \mathrm{IFN}-\gamma^{-} /^{-}$had lower number of apoptotic cells and decreased caspase-3 expression in $\mathrm{LG}$. CD25 ${ }^{-} /{ }^{-} \mathrm{IL}-17^{-} /-\mathrm{IFN}-\gamma^{-} /^{-}$had lower total lymphocytic cell infiltration at $8 \mathrm{~W}(48 \%), C D 4^{+} T$ cell infiltration and expression of IFN- $\gamma R$ and apoptotic ${ }^{+}$cells in the LG and increased tear EGF concentration in tears.

Conclusions: IFN- $\gamma$ is critical for $L G$ destruction and secretory dysfunction in the CD25 $/$ model of SS. Altered balance between IFN- $\gamma$ and IL-13 in the CD25 $5^{-} \mid \mathrm{LL}-17 \mathrm{~A}^{-} /^{-}$mice accelerates $\mathrm{LG}$ destruction by increasing glandular apoptosis and facilitating apoptosis through increased expression of IFN-YR by glandular epithelium and activation of caspases. Targeting both IFN- $\gamma$ and IL-17 may be beneficial for treating the LG inflammation in SS.
\end{abstract}

\footnotetext{
* Correspondence: cintiadp@bcm.edu

Ocular Surface Center, Department of Ophthalmology, Cullen Eye Institute, Baylor College of Medicine, 6565 Fannin Street, NC505G, Houston, TX 77030, Texas, USA
} 


\section{Introduction}

Sjögren's syndrome (SS) is an autoimmune disorder characterized by progressive lymphocytic infiltration of the salivary and lacrimal gland (LG) leading to dry eye and dry mouth. Glandular infiltrates are composed of a mix of dendritic cells, macrophages, $\mathrm{CD}^{+}, \mathrm{CD}^{+}$, natural killer (NK), Foxp $3^{+}$, B cells, dendritic cells [1]. Despite expanding efforts to define the immunopathology of SS, the underlying molecular mechanisms responsible for the impaired secretory function of the inflamed LG remain incompletely understood, as several molecules have been known to impair secretion in in vitro models, including interleukin (IL) IL-1, IL-6, nitric oxide (NO), anti-muscarinic receptor, anti-Ro immunoglobulin G (IgG) [2-5]. Mouse models that recapitulate some features of SS have been used to study the pathogenesis, including the IL-2 receptor alpha chain (CD25) knockout (KO) $[6,7]$.

IL-2 signals through its heterodimer receptor composed of three individual chains. CD25 binds IL-2 with high affinity and it is considered its main receptor. Mice lacking CD25 have phenotype similar to mice lacking IL-2 itself $[8,9]$. As IL-2 is responsible for expansion and differentiation of $\mathrm{T}$ regulatory cells (Tregs) and also activation-induced cell death, autoimmunity arises in both IL-2 ${ }^{-/-}$and CD $25^{-/-}$strains $[6,8,10]$. The CD25KO mouse develops spontaneous multiorgan inflammatory disease, inclusive of exocrine glands and gastrointestinal tract, and a profound hemolytic anemia that leads to early mortality. The spontaneous dacryoadenitis that develops in these mice is age dependent, with $50 \%$ of the LG infiltrated by 8 weeks (W), evolving to complete atrophy and periductal fibrosis at age $16 \mathrm{~W}$ [7]. Our previous studies with this mouse strain have found elevated IL-1 $\beta$, IL-17 and interferon-gamma (IFN- $\gamma$ ) transcripts in the LG [7]. We have shown that IL-17A levels in the LG peak at 8 to $12 \mathrm{~W}$ with a steady decline after, suggesting that IL-17 could be involved in earlier disease development $[7,11]$. Similar to findings in the nonobese diabetic (NOD) strain [12], deletion of IFN- $\gamma$ in the CD25KO delays onset and severity of dacryoadenitis, but does not prevent development of lymphocytic infiltration [13].

IL-17-producing $\mathrm{T}$ lymphocytes have been recently shown to comprise a $\mathrm{T}$ helper (Th) lineage known as Th17 cells, which are distinct from Th1 and Th2 cells. Th1 cells contribute to host defense of viral, fungal, and intracellular bacterial infections, and are characterized by the production of IFN- $\gamma$. Th17 cells have been shown to be involved in the pathogenesis of many autoimmune and inflammatory diseases, inclusive of SS.

IL-13 regulate IFN- $\gamma$ both in vitro and in vivo [14]. In murine models of allergic asthma, mice repeatedly exposed to allergens or IL-13 develop goblet cell hyperplasia of the airway epithelium [15-17]. IL-13 has also antiapoptotic effects on airway and colonic epithelia, two tissues that are rich in goblet cells $[18,19]$. IL-13 is expressed by Th2 cells and plays a role in B cell activation.

The specific role of IL-17, IL-13 and IFN- $\gamma$ in the inflammation that develops in the CD25KO has not been evaluated. To accomplish this, we used several double knockouts (DKO), including a CD25/IL-17 DKO, a CD25/ IFN- $\gamma$ DKO as well as a CD25/IL-17/IFN- $\gamma$ triple KO (TKO) mouse. Herein we describe that deletion of IL-17 in the CD25KO model accelerates LG lymphocytic infiltration and acini apoptosis, due to a high IFN- $\gamma$ receptor, high tumor necrosis factor (TNF)-related apoptosisinducing ligand (TRAIL), Fas-ligand (Fas-L) and high caspase- 3 and -9 and low local IL-13/IFN- $\gamma$ ratio, while the deletion of IFN- $\gamma$ decreases caspase activity levels and number of terminal deoxynucleotidyl transferase dUTP nick end labeling (TUNEL)-positive $(+)$ cells. Deletion of IL-17A and IFN- $\gamma$ in the CD25KO (creating a CD25/IL$17 / \mathrm{IFN}-\gamma$ TKO) ameliorates dacryoadenitis and improves glandular function, demonstrating that IFN- $\gamma$ is key to the autoimmunity in this model.

\section{Methods}

\section{Animals}

This research protocol was approved by the Baylor College of Medicine Center for Comparative Medicine, and it conformed to the standards in the ARVO Statement for Use of Animals in Ophthalmic and Vision Research.

CD25 $5^{+-}$(B6.129S4-IL-2ra $\left.{ }^{t m 1 D w} / J\right)$, IFN- $\gamma \mathrm{KO}$ and C57BL/6 J mice breeding pairs were purchased from Jackson Laboratories (Bar Harbor, ME, USA) for establishing of breeder colonies. IL-17KO mice were kindly provided by Dr. Yoichiro Iwakura [20].

To create a CD25/IL-17 double KO (CD25 $5^{-/} \mathrm{IL}-17^{-1-}$; CD25/IL-17 DKO), IL-17KO mice were mated with $\mathrm{CD} 25^{+/-}$mice. F1 was genotyped and $\mathrm{CD} 25^{+/-} \mathrm{IL}-17^{+/-}$ mice were mated. F2 offspring were genotyped. CD $25^{-/-} \mathrm{IL}-$ $17^{-/-}$were obtained after interbreeding of CD $25^{+/-} \mathrm{IL}-17^{-/-}$ mice. The genotype of $\mathrm{KO}$ strains was confirmed using a previously reported protocol. Mice were used at 4, 8, 12, $16 \mathrm{~W}$. A minimum of 24 animals per age $(4,8,12,16$ W) per strain (CD25KO, IL-17KO and CD25/IL-17 DKO) were used: five (histology), six (flow cytometry), eight (gene expression), five (caspase activity). Tear collection was performed when mice were alive $(n=12)$. In some strains/age, up to 20 animals were used for flow cytometry and up to eight animals were used for caspase activity.

To create a CD25/IL-17/IFN- $\gamma$ triple TKO (CD25 $5^{-1-}$

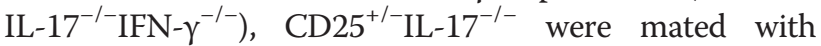
$\mathrm{CD} 25^{+/-} \mathrm{IFN}-\gamma^{-/-}$mice. $\mathrm{F} 1$ was genotyped and $\mathrm{CD} 25^{+/-} \mathrm{IL}-$ $17^{+/-} \mathrm{IFN}-\gamma^{+/-}$were mated again. F2 offspring was genotyped and $\mathrm{CD} 25^{+/-} \mathrm{IL}-17^{-/-} \mathrm{IFN}-\gamma^{-/-}$(IL-17/IFN- $\gamma$ DKO) were used as breeders to generate CD25/IL-17/IFN- $\gamma$ 
TKO mice. The IL-17/IFN- $\gamma$ DKO bred very slowly and very few CD25/IL-17/IFN- $\gamma$ TKO mice were generated. The genotype of KO strains was confirmed using a previously reported protocol. CD25/IL-17/IFN- $\gamma$ TKO and IL$17 /$ IFN- $\gamma$ DKO mice were used at 8,12 , and $16 \mathrm{~W}$ : five (histology), twelve (flow cytometry). An additional six $(4 \mathrm{~W})$ and twelve C57BL/6 mice (six for 4 and $8 \mathrm{~W}$ ) were used for histology, tear epidermal growth factor (EGF) assay and serum collection.

To create a CD25/IFN- $\gamma$ DKO (CD25 $\left.{ }^{-/-} \mathrm{IFN}_{-} \gamma^{-/-}\right)$, IFN- $\gamma \mathrm{KO}$ mice were mated with $\mathrm{CD} 25^{+/-}$mice. F1 was genotyped and $\mathrm{CD} 25^{+/-} \mathrm{IFN}-\gamma^{+/-}$mice were mated. F2 offspring were genotyped. CD $25^{-1-} \mathrm{IFN}-\gamma^{-/-}$were obtained after interbreeding of $\mathrm{CD} 25^{+/-} \mathrm{IFN}-\gamma^{-/-}$mice as previously described [13]. CD25/IFN- $\gamma$ DKO were used at 4 and $8 \mathrm{~W}$ : four animals for histology and four animals for gene expression.

\section{Histology and measurement of total infiltration}

Extraorbital LG were excised, fixed in 10\% formalin, paraffin embedded, and $8-\mu \mathrm{m}$ sections were cut as previously described [13]. Sections were stained with hematoxylin and eosin (H\&E) for evaluating morphology. The area of lymphocytic infiltration was circumscribed in digital images of H\&E-stained sections as previously described [7]. The percentage infiltration was calculated as area of infiltration $\times 100 /$ total area.

\section{Immunohistochemistry (IHC) and laser confocal microscopy}

Extraorbital LG from each strain/age $(n=5)$ were excised, embedded in optimal cutting temperature compound (VWR, Suwanee, GA, USA), and flash frozen in liquid nitrogen and stored at -80c.

IHC in LG cryosections was performed by using CD4 (BD Pharmingen, San Jose, CA, USA; clone H129.9, 10 $\mu \mathrm{g} / \mathrm{ml}$ ), CD8a (BD Pharmingen; clone 53e6.7, $3.125 \mu \mathrm{g} /$ $\mathrm{ml}$ ), or CD19 (Abcam, Cambridge, MA, USA; clone 6D5, $2 \mu \mathrm{g} / \mathrm{ml}$ ) antibodies. Staining was performed with appropriate biotinylated secondary antibodies (all from BD Pharmingen) and a Vectastain Elite ABC kit with Nova Red reagents (Vector Laboratories, Burlingame, CA, USA). Secondary antibody alone and appropriate anti-mouse isotype (BD Biosciences, San Diego, CA, USA) were used as controls. Six sections from each animal/group/time point were examined and photographed with a microscope equipped with a digital camera (Eclipse E400 with a DS-Fi1; Nikon, Melville, NY, USA).

Immunofluorescent staining in LG cryosections was performed by using primary antibodies against Fas- $\mathrm{L}$ or IFN- $\gamma$ receptor (1:100 for both, sc-834 and sc-703, respectively; Santa Cruz Biotechnology, Dallas, TX, USA). The tissue sections (two slides per animal) for immunofluorescent staining were fixed in acetone at $-20^{\circ} \mathrm{C}$ for 10 minutes, blocked in $20 \%$ normal goat serum in phosphate-buffered saline (PBS) for $60 \mathrm{mi}$ nutes and primary antibodies were applied and incubated for 1 hour at room temperature (RT). Secondary antibody, Alexa-Fluor 488-conjugated goat anti-rabbit IgG (1:100 dilution) were applied, sections was incubated in a dark chamber for 1 hour, followed by counterstaining with propidium iodide (PI; $2 \mu \mathrm{g} / \mathrm{mL}$ in PBS) for 5 minutes. Secondary antibody alone was also performed as negative controls.

Digital confocal images $(512 \times 512$ pixels $)$ were captured with a laser scanning confocal microscope (LSM 510, with krypton-argon and He-Ne laser; Carl Zeiss Meditec, Inc., Thornwood, NY, USA) with 488$\mathrm{nm}$ excitation and 543-nm emission filters (LP505 and LP560, respectively; Carl Zeiss Meditec, Inc.) and were acquired with a $40 / 1.3 \times$ oil-immersion objective. Images from all samples were captured with identical photomultiplier tube gain settings and were processed with the microscope system (LSM-PC software; Carl Zeiss Meditec, Inc.).

\section{Flow cytometry analysis of infiltrating cells}

Single-cell suspensions of LG from all strains were prepared and stained for CD4, CD8 and B220 surface markers as previously reported [13]. The initial leukocyte gate in flow cytometry analysis was confirmed to have greater than $98 \%$ of $\mathrm{CD} 45^{+}$cells.

\section{RNA isolation and quantitative PCR}

Extraorbital LGs from IL-17KO, CD25KO, CD25/IL-17 DKO, and C57BL/6 were excised and total RNA was extracted and processed as previously described [13]. Eight samples per strain/age were used, and one sample consisted of pooled glands from the same animal. Firststrand cDNA was synthesized.

Quantitative real-time PCR was performed with specific minor groove binder (MGB) probes as previously published [21]. Murine MGB probes were IFN- $\gamma$ (Mm00801778), IL-13 (Mm00434165), IL-4 (Mm00445259), IL-5 (Mm 99999063), hypoxanthine phosphoribosyltransferase (HPRT1) (Mm00446968), caspase-3 (Mm00438045), caspase-8 (Mm00802247), caspase-9 (Mm01348848), major histocompatibility complex class II (MHC-II) (Mm00482914) TNF- $\alpha$ (Mm99999068), IL-1 $\beta$ (Mm 00434228), IL-17 (Mm00439618), IFN- $\gamma$ receptor (Mm 00599890), TRAIL (Mm01283606) and Fas-L (Mm 00438864). The HPRT-1 gene was used as an endogenous reference for each reaction. The results of real time PCR were analyzed by the comparative CT method and the results were normalized by the CT value of HPRT-1. The mean CT of relative mRNA level in the 4-W IL-17KO group was used as the calibrator. 


\section{Tear washings and EGF enzyme-linked immunosorbent assay (ELISA)}

ELISA was performed to measure EGF concentrations in tear fluid washings using a commercial ELISA kit (R\&D Systems, Minneapolis, MN, USA) as previously described [13]. Tear fluid washings were collected from 12 animals/ strain/age [13]. One sample consisted of tear washings from both eyes of one mouse pooled $(2 \mu \mathrm{L})$ in PBS $+0.1 \%$ bovine serum albumin (BSA) $(8 \mu \mathrm{L})$ and stored at $-80^{\circ} \mathrm{C}$ until the assay was performed. Results are presented as mean \pm standard deviation (SD) (pg/ml).

\section{Caspase-3, -8 , and -9 activation fluorometric assays}

The activation of caspase-3, -8 , and -9 was measured in LG lysates according to the manufacturer's protocol (K105-200, K112-200, and K118-200, respectively; BioVision, Inc., Mountain View, CA, USA). Protein concentration was measured using a micro BSA protein assay kit (Thermo Fisher Scientific, Waltham, MA, USA). Five to eight samples per age/strain were used. Caspase-3, -8, and -9 activities were measured ( $50 \mu \mathrm{g} / \mathrm{sample}$ ) by following the cleavage of the fluorescent substrate analogs in a fluorescent plate reader (Tecan Infinite M200, Magellan V6.55 software; Tecan, Männedorf, Switzerland) with 400-nm excitation filter and 505-nm emission filter. The results were exported and averaged.

\section{TUNEL assay}

The TUNEL assay was performed with a kit (ApopTag; Intergen Co., Purchase, NY, USA), in cryosections of LG ( $\mathrm{n}=3 /$ strain/age), as previously described [22]. $\mathrm{TUNEL}^{+}$ cells were counted in digital images at $20 \mathrm{X}$ within each group and results averaged.

\section{IL-4, IL-5, IL-13, IL-17 and IFN- $\gamma$ LUMINEX assay in serum}

Concentrations of IL-4, IL-5, IL-13, IL-17 and IFN- $\gamma$ in serum were measured using a multiplex Mouse Cytokine Magnetic Bead Panel (Millipex Map Kit; EMD Millipore Corp, Billerica, MA, USA). Serum was collected from mice ( $n=4$ to $8 /$ strain) through cardiac puncture immediately after euthanasia and frozen at $-80^{\circ} \mathrm{C}$ until ready to use. A $25 \mu \mathrm{l} /$ sample was used according to the manufacturer's protocol. Labeled cytokines were read by a Luminex 100 with xPONENT 3.1 (Luminex, Austin, TX, USA). At least 50 events per bead were read and the data were analyzed using Millipex Analyst software (EMD Millipore).

\section{Statistical analysis}

Two-way analysis of variance (ANOVA) or KruskallWallis test with Tukey's post hoc testing was used for statistical comparisons with alpha of 0.05 . These tests were performed using GraphPad Prism 6.0 software (GraphPad Software Inc., San Diego, CA, USA).

\section{Results}

Deletion of IL-17A in the CD25KO worsen dacryoadenitis

Our previous studies showed that CD25KO mice have increased expression of both IL-17A and IFN- $\gamma$ transcripts in LG tissue [7] and that deletion of IFN- $\gamma$ delayed the onset and severity of dacryoadenitis in this strain [13]. To dissect the specific contribution of IL-17A in this model, we compared CD25KO and CD25/IL-17 DKO mice with age-matched IL-17KO mice. Neither the CD25KO [13], nor the IL-17KO strain have a gender bias (data not shown). No gender difference in severity of LG infiltration in the CD25/IL-17 DKO or CD25/IL-17/IFN- $\gamma$ TKO strain was observed; therefore, the data represent an average of both genders (1:1) for each parameter/age. Increased mortality was seen in CD25/IL-17 DKO strain compared to CD25KO strain, as early as $5 \mathrm{~W}$, with few mice reaching $16 \mathrm{~W}$ of age. Sparse cell infiltration was observed around the ducts in IL-17KO LG, while both CD25KO and CD25/IL-17 DKO showed increased lymphocytic infiltration (approximately $40 \%$ and approximately $80 \%$ respectively, Figure $1 \mathrm{~A}, \mathrm{~B}$ ) at $4 \mathrm{~W}$. After $8 \mathrm{~W}$, both CD25KO and CD25/IL-17 DKO had similar total acinar loss, ductal proliferation, which progressed to atrophy by $16 \mathrm{~W}$. Normal acini were seen in CD25/IL-17 DKO LG only at $4 \mathrm{~W}$ (Figure $1 \mathrm{~A}, \mathrm{~B}$ ).

As a measurement of LG secretory function, EGF concentration in tears was measured as previously described [13]. A progressive increase in EGF concentration in tears of IL-17KO mice was seen as they aged, suggesting normal maturation and function of LG epithelia (Figure 1C). Both CD25KO and CD25/IL-17 DKO had significantly lower EGF concentration compared to IL-17KO mice at all ages.

CD25/IL-17 DKO showed a significantly greater percentage of $\mathrm{CD}^{+}$cells than the CD25KO strain at 4 and $12 \mathrm{~W}$ (Figure 2A). Flow cytometry showed a predominance of $\mathrm{CD}^{+} \mathrm{T}$ cells over CD4 ${ }^{+} \mathrm{T}$ cells in CD25KO and CD25/IL17 DKO LGs at all ages compared to IL-17KO mice (Figure 2C). CD4 and $\mathrm{CD}^{+} \mathrm{T}$ cells were mainly seen around ducts (Figure 2B, D). CD25KO had the greatest percentage of $\mathrm{B}^{2} 20^{+}$cells compared to IL-17KO (at all ages) and higher percentage than CD25/IL-17 DKO (Figure 2E) at 8 and $12 \mathrm{~W}$. Minimal $\mathrm{CD}_{19^{+}} \mathrm{B}$ cell infiltration was observed in IL-17KO at all ages (Figure 2F). Sparse infiltrating $\mathrm{CD}_{19}{ }^{+}$cells were seen in CD25/IL-17 DKO and CD25KO at $4 \mathrm{~W}$ whereas they were easily identified as these mice aged (Figure 2F). Two types of $\mathrm{CD} 19^{+} \mathrm{B}$ cell infiltration were observed: the first resembled IL-17KO LGs, where B cells were dispersed throughout the gland and did not accumulate in foci, while the second was suggestive of germinal center formation within the LG (Figure 2F, aged 8 to $16 \mathrm{~W}$ ).

Taken together, these results show that deletion of IL$17 \mathrm{~A}$ in the CD25KO model of SS accelerated LG destruction and promoted progressive increased lymphocytic infiltration. 


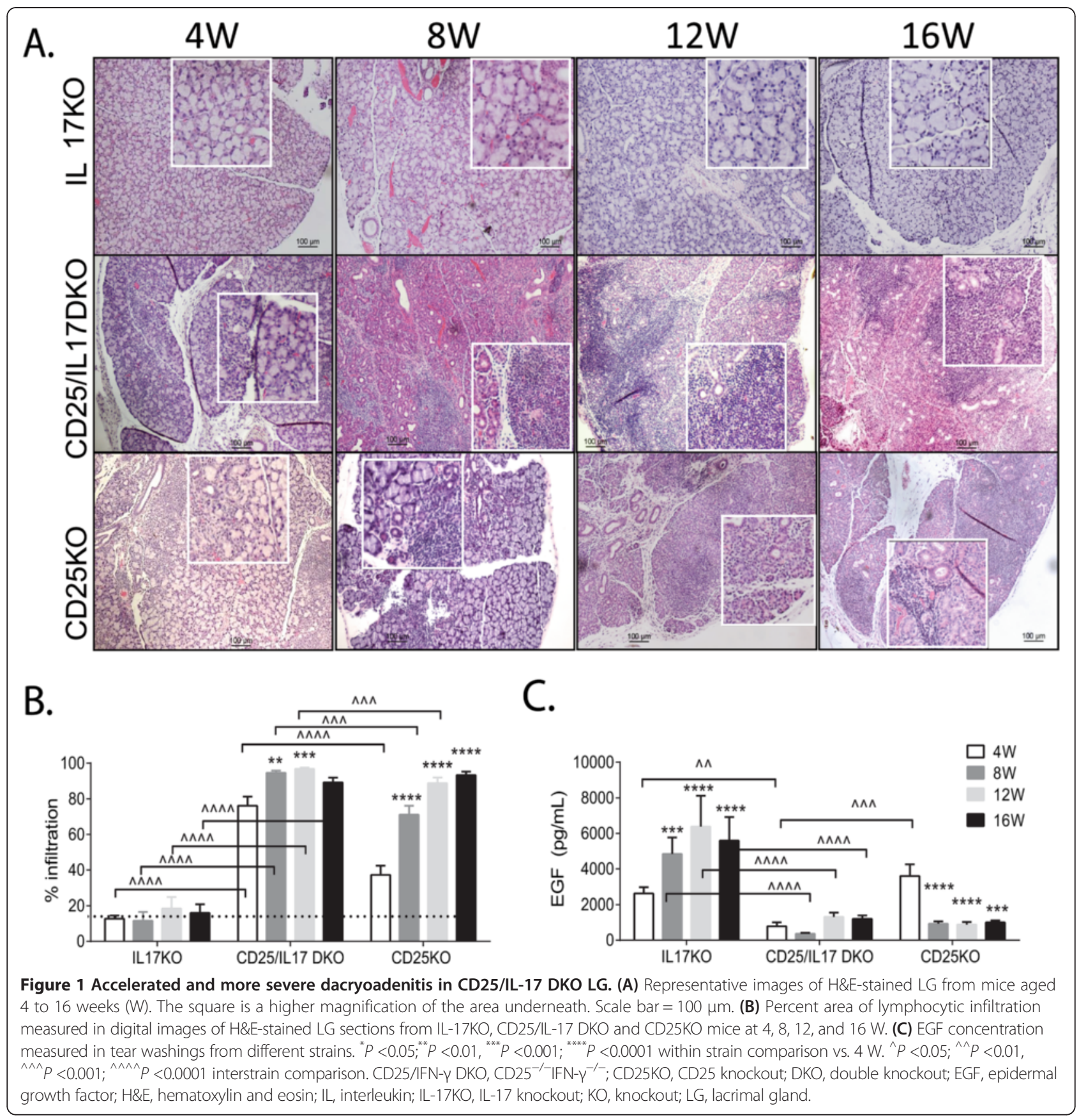

\section{Increased inflammation and Th-related cytokines in CD25/}

\section{IL-17 DKO LG}

To investigate the phenotype of infiltrating cells, we evaluated the expression of MHC II, inflammatory cytokines (IL-1 $\beta$, TNF- $\alpha$ ), IL-13, IFN- $\gamma$, IFN- $\gamma$ receptor (IFN- $\gamma$ R) and IL-13 using the $4 \mathrm{~W}$ IL-17KO LG as calibrator control, since this control strain had minimal $\mathrm{T}$ cell infiltration (Figure 3). Real-time PCR analysis showed that IL-1 $\beta$, TNF- $\alpha$, IFN- $\gamma$ and MHC II were all significantly elevated in CD25/IL-17 DKO and CD25KO compared to IL-17KO LG at all ages, although aging from 4 to $16 \mathrm{~W}$ significantly increased levels of IL-1 $\beta$, TNF- $\alpha$ and MHC II transcripts in IL-17KO mice.

Expression of IL-1 $\beta$ mRNA was higher in CD25KO at $4 \mathrm{~W}$, and expression of IFN- $\gamma$ mRNA was higher at both $4 \mathrm{~W}$ and $8 \mathrm{~W}$. By $8 \mathrm{~W}$ and $12 \mathrm{~W}$, expression of both transcripts was higher in CD25/IL-17 DKO.

Although the level of TNF- $\alpha$ transcripts was similar in $\mathrm{CD} 25 \mathrm{KO}$ and CD25/IL-17 DKO at $4 \mathrm{~W}$, it increased steadily in CD25KO from 4 to $12 \mathrm{~W}$, while in the CD25/ IL-17 DKO it did not change until $16 \mathrm{~W}$, when it was significantly higher than CD25KO. 


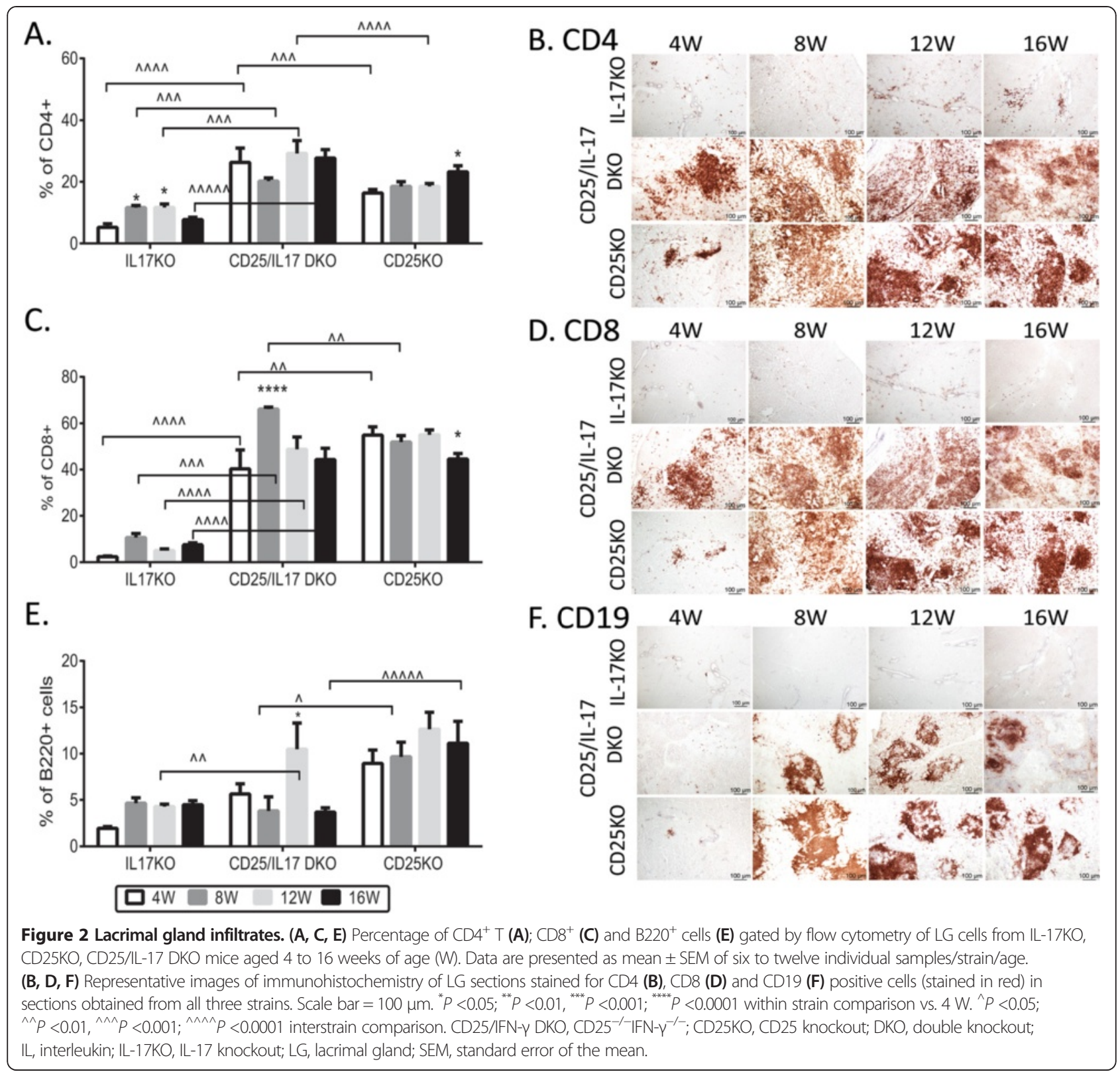

Interestingly, MHC II expression in the CD25KO had a bimodal distribution peaking at $8 \mathrm{~W}$ (approximately 27-fold) and $16 \mathrm{~W}$ (31-fold), while in the CD25/IL-17 DKO it increased gradually, reaching the same level as the $\mathrm{CD} 25 \mathrm{KO}$ at $12 \mathrm{~W}$.

IL-13 has been described to be antiapoptotic in colonic and airway epithelial cells as well as conjunctival fibroblasts [18,19,23]. Expression of IL-13 mRNA in the CD25KO increased over a biphasic time course. Expression in CD25/IL-17 DKO was markedly suppressed compared to $\mathrm{CD} 25 \mathrm{KO}$ at $4 \mathrm{~W}, 8 \mathrm{~W}$, and $16 \mathrm{~W}$ (Figure 3). IL-4 and IL-5 transcripts were barely detected in some samples and were undetected in many samples.
Our results indicate that CD25/1L-17 DKO mice have greater expression of IL-1 $\beta$, while lower levels of IL-13 than CD25KO, but both strains had increased TNF- $\alpha$ and MHC II compared to IL-17KO. CD25KO LG have increased IL-17A, IFN- $\gamma$ and IL-13, while CD25/IL-17 DKO mice have only elevated IFN- $\gamma$. IL-13 may have a protective role counteracting IFN- $\gamma$, as higher levels of IL-13 transcripts were seen in CD25KO mice, which had less severe disease than the CD25/IL-17 DKO.

\section{Systemic Th2 cytokines are suppressed in the CD25/LL-17 DKO compared to the CD25KO}

IL-17A serum levels were 10-fold higher in CD25KO mice than C57BL/6 mice at $8 \mathrm{~W}(78.82 \pm 48$ vs. $7.57 \pm$ 


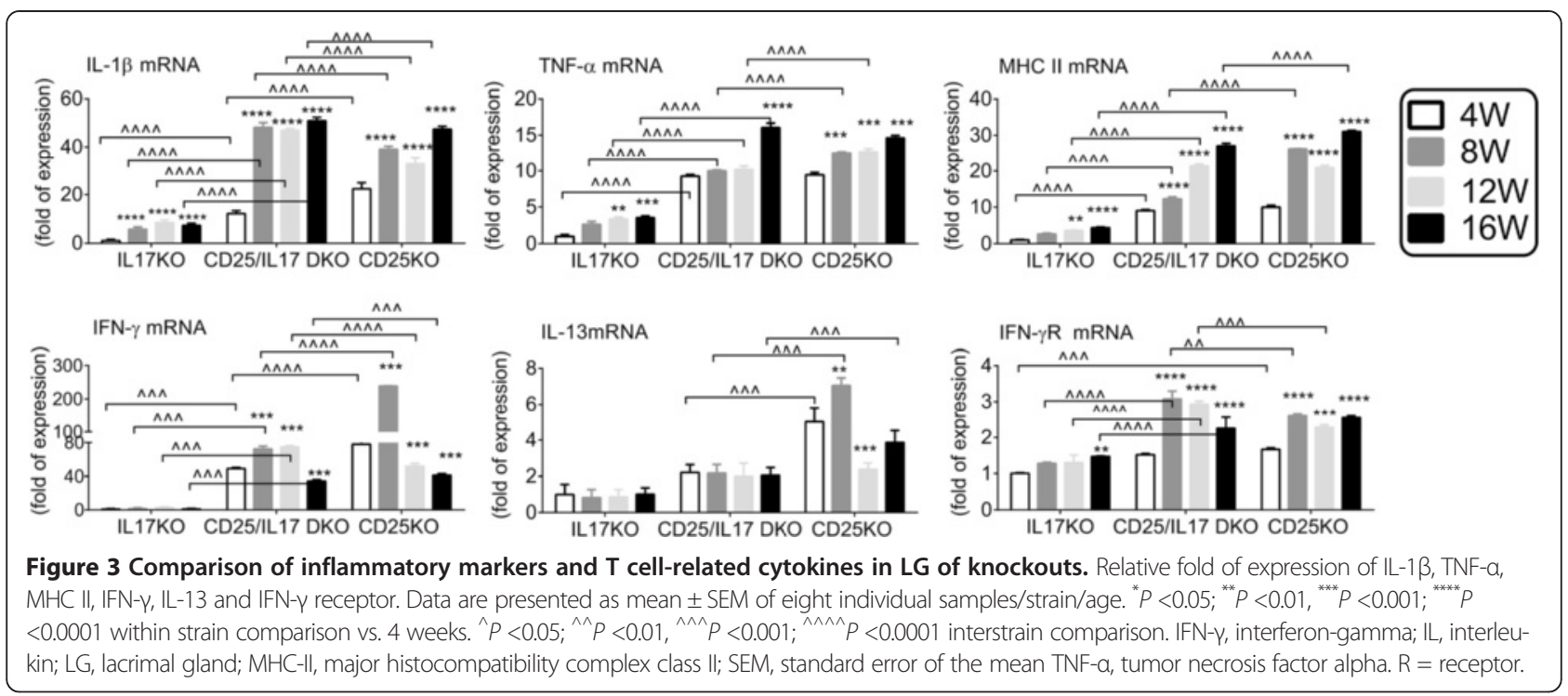

$4.04 \mathrm{pg} / \mathrm{mL}$, respectively, $P=0.001$ ). A progressive systemic increase in IFN- $\gamma$ was measured in serum of CD25/IL-17 DKO mice as they aged from 4 to $12 \mathrm{~W}$ (Figure 4A). IL-13 levels in serum mirrored gene expression in the LG as they were significantly elevated in
CD25KO at all ages compared to CD25/IL-17 DKO (Figure 4A). IL-4 and IL-5 levels in serum of CD25KO were significantly increased in $\mathrm{CD} 25 \mathrm{KO}$ at 4 and $8 \mathrm{~W}$ compared to CD25/IL-17 DKO and low levels were measured in IL-17KO at all ages (Figure 4A). The IL-13/IFN- $\gamma$
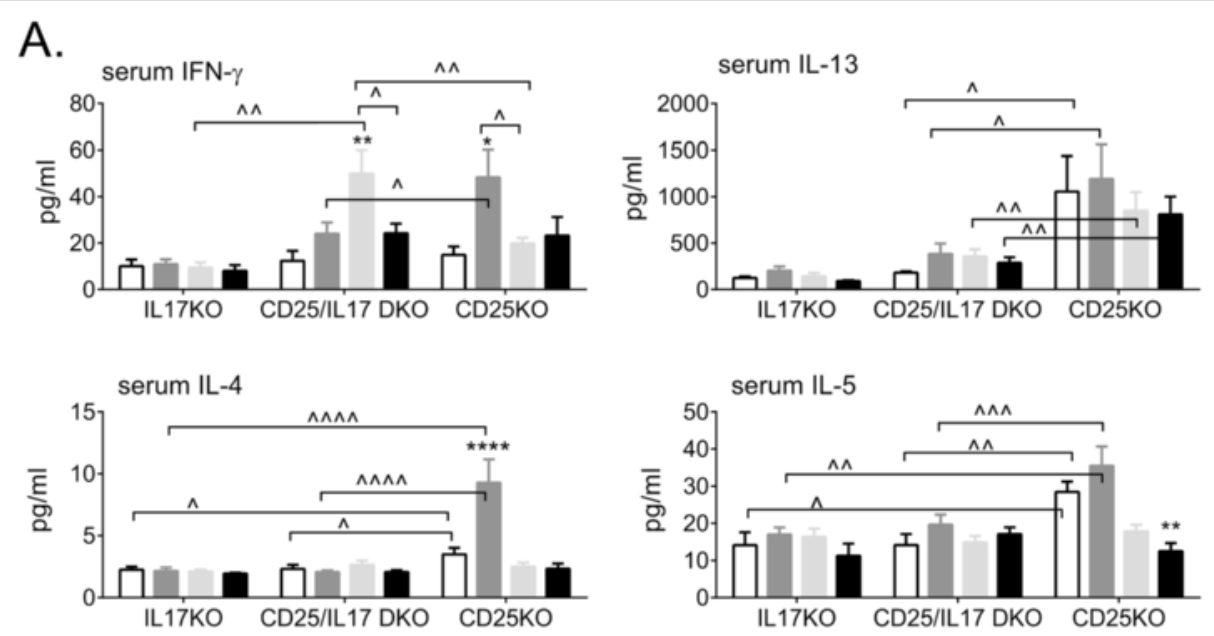

B.

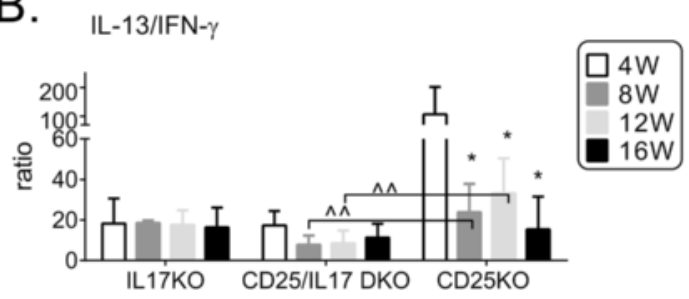

Figure 4 Comparison of T helper cell-related cytokines in serum of knockouts. (A) Concentration of IFN- $\gamma$, IL-13, IL-4 and IL-5 in serum from IL-17KO, CD25/LL-17 DKO, CD25KO mice. Data are presented as mean \pm SEM of eight individual strains/ages. (B) Bar graph showing mean \pm SEM of IL-13/IFN- $\gamma$ ratio of serum from IL-17KO, CD25/LL-17 DKO, CD25KO mice. ${ }^{*} P<0.05 ;{ }^{* * *} P<0.01,{ }^{* * *} P<0.001 ;{ }^{* * * *} P<0.0001$ within strain comparison vs. 4 weeks. ${ }^{\wedge} P<0.05 ;{ }^{\wedge \wedge} P<0.01,{ }^{\wedge \wedge} P<0.001 ;{ }^{\wedge \wedge \wedge} P<0.0001$ interstrain comparison. CD25/IFN- $\gamma$ DKO, CD25 ${ }^{-1-}$ IFN- $\gamma^{-1-}$; CD25KO, CD25 knockout; DKO, double knockout; IFN- $\gamma$, interferon-gamma; IL, interleukin; IL-17KO, IL-17 knockout; LG, lacrimal gland; SEM, standard error of the mean; W, weeks. 
ratio in sera using the mean values for all three strains showed that CD25KO have a higher IL-13 systemic response than CD25/IL-17 DKO (Figure 4B). The IL-4/IFN$\gamma$ and IL-5/IFN- $\gamma$ ratio in CD25/IL-17 DKO was also lower compared to CD25KO mice (data not shown).

Taken together, these results showed that CD25KO mice have high levels of systemic Th1, Th17 and Th2 signature cytokines but an unchecked systemic elevated Th1 response (with low levels of Th2) is observed with aging in the CD25/IL-17 DKO mice.

\section{Role of IL-17 and IFN- $\gamma$ in the LG apoptosis in CD25KO mice}

We have previously demonstrated a proapoptotic role of IFN- $\gamma$ in our inducible dry eye model, as antibody neutralization of IFN- $\gamma$ prevented desiccation-induced goblet cell loss [24]. Because we found high IFN- $\gamma$ and low IL-13 transcripts in CD25/IL-17 DKO mice, we hypothesize that these mice might be more susceptible to the apoptotic effects of IFN- $\gamma$ due to its lower IL-13 levels, since IL-13 has been shown to have antiapoptotic effects and to downregulate IFN- $\gamma \mathrm{R}$ expression $[18,19]$. To address this, we investigated IFN- $\gamma \mathrm{R}$ expression by real-time PCR and immunostaining. Both CD25KO and CD25/IL17 DKO had higher expression of IFN- $\gamma \mathrm{R}$ at $4 \mathrm{~W}$ compared to IL-17KO; but greater mRNA levels were observed in CD25/IL-17 DKO LG compared to CD25KO at 8 and $12 \mathrm{~W}$ (Figure 5A). Immunostaining evaluated protein expression at 4 and $8 \mathrm{~W}$ because these ages had the greatest differences. Minimal immunoreactivity for IFN$\gamma \mathrm{R}$ was present in IL-17KO and C57BL/6 (Figure 5A), while increased immunostaining was seen in the LG ducts in both CD25KO and CD25/IL-17 DKO at $4 \mathrm{~W}$, which increased as these mice aged to $8 \mathrm{~W}$.

Since expression of Fas-L on infiltrating lymphocytes has been shown to cause apoptosis to surrounding cells [25-27], we investigated the expression of Fas-L and TRAIL. Fas-L was significantly increased in both CD25KO and CD25/IL-17DKO compared to IL-17KO, and IL-17 DKO had significantly higher levels of Fas-L at 4, 8 and 16 W compared to CD25KO.

There was an age-progressive increase in TRAIL mRNA levels in CD25/IL-17 DKO LG from 4 to $8 \mathrm{~W}$ and it was significantly higher than CD25KO LG at $12 \mathrm{~W}$ (Figure 5B).

Because Fas-L and IFN- $\gamma$-mediated apoptosis ultimately involves activation of caspases [24,28], we investigated apoptotic pathway mediators in LG lysates. Caspase- 3 is the final common apoptosis pathway, while caspase- 9 is involved in the intrinsic pathway and caspase- 8 is involved in the extrinsic one. Caspase-3, -8, -9 mRNA levels were elevated in CD25/IL-17 DKO and CD25KO compared to IL-17KO at 8, 12 and $16 \mathrm{~W}$ (Figure 5C). A progressive increase in caspase- 3 and -8 transcripts expression was seen in CD25/IL-17 DKO LG as these mice aged. Significantly higher levels of caspase- $3,-8$ and -9 were seen in CD25KO at $4 \mathrm{~W}$ compared to the CD25/IL-17 DKO. Caspase-3 transcripts were significantly upregulated in CD25/IL-17 DKO, while caspase- 8 and -9 were equally elevated in both $\mathrm{CD} 25 \mathrm{KO}$ and CD25/IL-17 DKO at $8 \mathrm{~W}$. Results from gene expression were confirmed by caspase activity assays. IL-17KO had the lowest caspase activity levels among all three strains, corroborating the PCR results. Compared to CD25KO mice, CD25/IL-17 DKO LG had significantly higher caspase-3, and -9 activity levels at $4 \mathrm{~W}$ and significantly higher caspase- $3,-8$ and -9 activity levels at $8 \mathrm{~W}$ (Figure 5D). An increase with aging from 4 to $8 \mathrm{~W}$ within the CD25/IL-17 DKO LG was observed for caspase- 3 and -8 .

TUNEL detects fragmented DNA, another sign of apoptosis. Increased TUNEL ${ }^{+}$cells were seen in LG sections of both CD25/IL-17 DKO and CD25KO at $4 \mathrm{~W}$ compared to IL-17KO LG control $(459 \pm 16.72$ and $281 \pm 14.29$ vs. $81.67 \pm 7.56 \mathrm{TUNEL}^{+}$cells/20X field, $P<0.0001$ for both, respectively, Figure $5 \mathrm{E}$ and $\mathrm{F}$ ). $\mathrm{TUNEL}^{+}$cells were seen in the glandular epithelial cells, but not in the infiltrating cells (Figure 5E). At $8 \mathrm{~W}$, a further increase in $\mathrm{TUNEL}^{+}$ cells was seen in the CD25/IL-17 DKO mice compared to its baseline $\left(1,100.67 \pm 101.85\right.$ vs. $459 \pm 16.72$ TUNEL $^{+}$ cells/20X field, $P<0.0001$ ).

These results suggest that increased IFN- $\gamma R$ expression in the CD25/IL-17 DKO mice sensitizes them to IFN- $\gamma$-induced apoptosis and these changes may be potentiated in the low antiapoptotic IL-13 environment of this strain compared to CD25KO.

\section{Deletion of IFN- $\gamma$ in CD25KO decreases apoptosis}

We have shown that antibody neutralization of IFN- $\gamma$ prevented desiccation-induced increase in caspase-3 mRNA and immunoreactivity while exogenous administration of IFN- $\gamma$ during desiccating stress induced caspase-9 mRNA and activity $[24,29]$. To confirm the role of IFN- $\gamma$ in promoting glandular apoptosis in the CD25KO model, we evaluated caspase activity in LG protein lysates and performed TUNEL assay in CD25/IFN- $\gamma$ DKO LG cryosections at $4 \mathrm{~W}$ and $8 \mathrm{~W}$. These mice have significantly delayed and less severe dacryoadenitis compared to $\mathrm{CD} 25 \mathrm{KO}$ mice at $8 \mathrm{~W}$ [10]. We observed significantly lower caspase-3 and -9 activity levels in CD25/IFN- $\gamma$ DKO LG compared to CD25KO at $8 \mathrm{~W}$ and CD25/IL-17 DKO (Figure 5D). Although the level of caspase- 8 activity was significantly lower than the CD25/IL-17 DKO, it was not different from CD25KO mice (Figure 5D).

CD25/IFN- $\gamma$ DKO at 4 and $8 \mathrm{~W}$ had very few TUNEL $^{+}$ cells, and they were significantly lower than CD25KO parental strain $(101 \pm 14$ and $143 \pm 17.44$ vs. $281 \pm 14.29$ and $429 \pm 23.24 \mathrm{TUNEL}^{+}$cells/20X field, $P<0.001$ and $P<0.0001$, respectively, Figure $5 \mathrm{E}$ and F). These results confirm the pathogenic role of IFN- $\gamma$ in inducing glandular 
A.

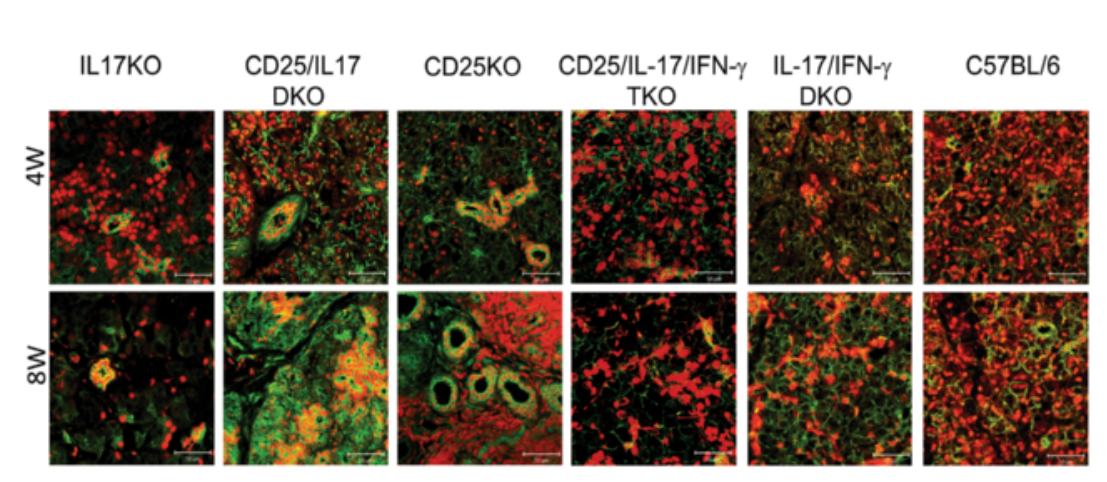

C.

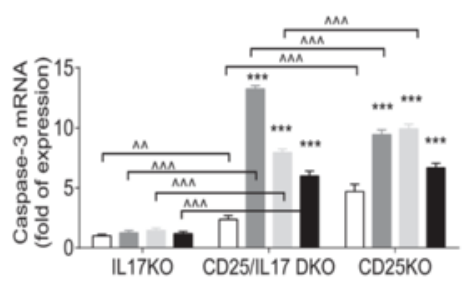

D.

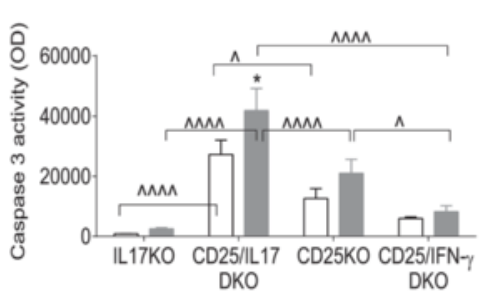

E. TUNEL
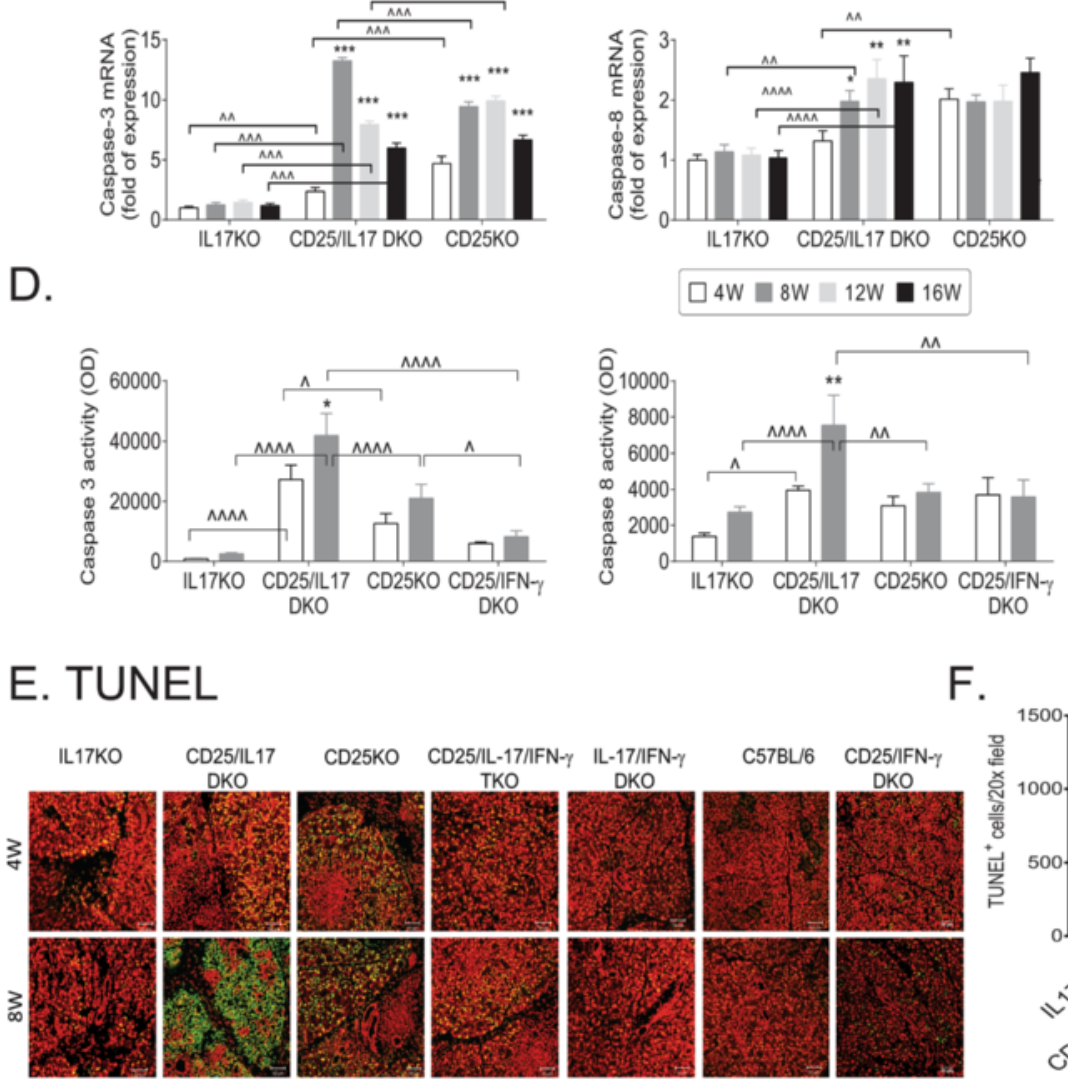

$\square 4 \mathrm{~W} \square \mathrm{BW} \square 12 \mathrm{~W} \boldsymbol{\square} 16 \mathrm{~W}$

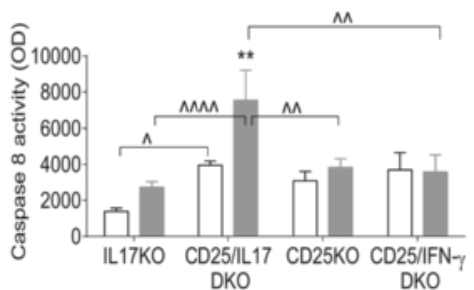

B.
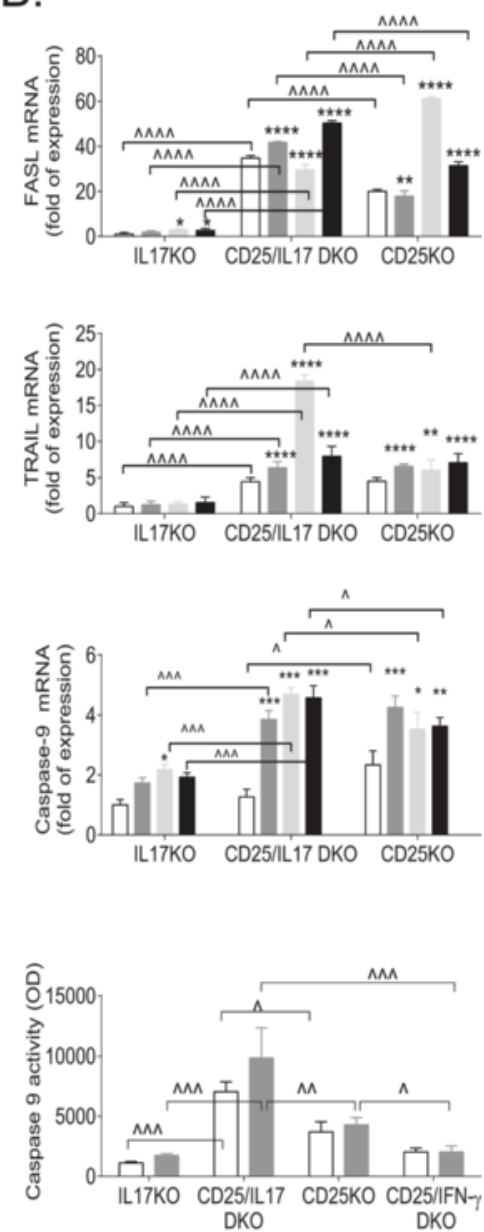

Figure 5 Comparison of apoptosis among different double knockouts. (A) Representative merged images of laser scanning immunofluorescent confocal micrographs of $L G$ immunostained for IFN- $\gamma$ receptor (IFN- $\mathrm{YR}$, green) with propidium idodide counterstaining (red) in IL-17KO, CD25KO, CD25/LL-17 DKO, CD25/ IL-17/IFN- - TKO, IL-17/IFN- $\gamma$ DKO and C57BL/6. Scale bar $=50 \mu \mathrm{m}$. (B-C) Relative fold of expression of Fas-L and TRAlL (B) and caspase-3, -8 and -9 (C) in LG lysates of IL-17KO, CD25/L-17 DKO and CD25KO mice aged 4 to 8 weeks (M). Data are presented as mean \pm SEM of eight individual samples/strains/ages. (D) Caspase-3, -8 and -9 activity assay results from LG lysates of IL-17KO, CD25/L-17 DKO, CD25KO and CD25/FN- - DKO mice aged 4 to 8 W. Data are presented as mean \pm SEM of five to eight individual samples/strains/ages. (E) Representative merged images of laser scanning fluorescent confocal micrographs of TUNELstained LG (green) with propidium iodide counterstaining (red) in IL-17KO, CD25KO, CD25/L-17 DKO, CD25/LL-17/IFN- $\mathrm{TKO}$, IL-17//FN- $\mathrm{DKKO}, \mathrm{C57BL/6}$ and CD25/IFN- $\gamma$ DKO mice used to generate the bar graphs in (F) Scale bar $=50 \mu \mathrm{m}$. F. TUNEL ${ }^{+}$cells (mean \pm standard deviation (SD)) among the different groups. ${ }^{*} P<0.05 ;{ }^{* * *} P<0.01,{ }^{* * *} P<0.001 ;{ }^{* * * * *} P<0.0001$ within strain comparison vs. $4 \mathrm{~W} .{ }^{\wedge} P<0.05 ;{ }^{\wedge \wedge} P<0.01,{ }^{\wedge \wedge} P<0.001 ;{ }^{\wedge \wedge \wedge} P<0.0001$ interstrain comparison. CD25/IFN-

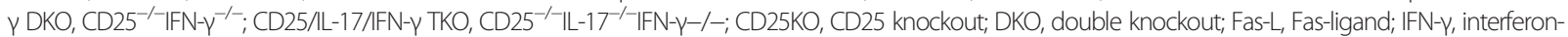
gamma; IL-17/IFN- $\mathrm{DKO}, \mathrm{CD} 25^{+/-} \mathrm{IL}-17^{-/}-1 \mathrm{FN}-\gamma^{-1-}$; IL, interleukin; IL-17KO, LL-17 knockout; LG, lacrimal gland; SEM, standard error of the mean; TKO, triple knockout; TNF, tumor necrosis factor; TRAIL, TNF-related apoptosis-inducing ligand; TUNEL, terminal deoxynucleotidyl transferase dUTP nick end labeling; W, weeks. 
apoptosis through intrinsic apoptosis pathway (caspase-9) as deletion of IFN- $\gamma$ in the CD25KO model significantly decreases caspase activity levels and $\mathrm{TUNEL}^{+}$cells.

\section{Deletion of IFN- $\gamma$ in CD25/IL-17 DKO ameliorates SS-like disease}

Next we investigated if deletion of IFN- $\gamma$ in the CD25/IL17 DKO mouse would diminish LG disease by generating a CD25/IL-17/IFN- $\gamma$ TKO mouse $\left(\mathrm{CD} 25^{-/-} \mathrm{IL}^{-17^{-/}}\right.$IFN$\gamma^{-/-}$) and compared to IL-17/IFN- $\gamma$ DKO littermates $\left(\mathrm{CD} 25^{+/-} \mathrm{IL}-17^{-l-} \mathrm{IFN}-\gamma^{-/-}\right)$. Similar to parental strains, no gender predilection was seen (not shown).

IL-17/IFN- $\gamma$ DKO had normal-appearing LG with minimal lymphocytic infiltration at all ages (4 to $16 \mathrm{~W}$ ), while in CD25/IL-17/IFN- $\gamma$ TKO mice areas of immune infiltrates were seen at $8 \mathrm{~W}(20 \%$ of total LG) and progressively increased up to $16 \mathrm{~W}$, compromising about $60 \%$ of the LG area (Figure 6A and B). Tear EGF concentration in CD25/IL-17/IFN- $\gamma$ TKO and IL-17/IFN- $\gamma$ DKO mice was in the normal range at $8 \mathrm{~W}$; however, a significant decline in tear EGF concentration was seen in CD25/IL$17 / \mathrm{IFN}-\gamma$ TKO as they aged to $16 \mathrm{~W}$ (Figure 6C).

Histologically, a mix of $\mathrm{CD} 4^{+}, \mathrm{CD}^{+}$and $\mathrm{CD} 19^{+}$cells was seen in the LG, with a greater number of $\mathrm{CD}^{+}$(Figure 6D) and $\mathrm{CD}^{+}$(not shown) in the CD25/IL-17/IFN- $\gamma$ TKO compared to IL-17/IFN- $\gamma$ DKO mice. Flow cytometric analyses indicated that the immune cell aggregates consisted of $\mathrm{CD}^{+}, \mathrm{CD}^{+}{ }^{+} \mathrm{T}$ cells, and $\mathrm{B}$ lymphocytes (Figure $6 \mathrm{E}$ ). There was an increased percentage of $\mathrm{CD}^{+}$and $\mathrm{CD} 8^{+}$in CD25/IL-17/IFN- $\gamma$ TKO compared to IL-17/IFN- $\gamma$ DKO mice $(8 \mathrm{~W}$ to $16 \mathrm{~W})$, with a predominance of $\mathrm{CD}^{+}$cells. There was a significant increase in $\mathrm{CD} 4^{+}$cells at $12 \mathrm{~W}$ compared to $8 \mathrm{~W}$ in CD25/IL-17/IFN- $\gamma$ TKO mice, paralleling increased lymphocytic infiltration seen in histologic sections. IL-17/IFN- $\gamma$ DKO had the highest percentage of B cells (Figure 6E).

Gene expression could not be evaluated in the LG of CD25/IL-17/IFN- $\gamma$ TKO mice due to difficultly breeding of this strain. To investigate whether the CD25/IL-17/ IFN- $\gamma$ TKO mice had a compensatory elevation of IL-13 as seen in CD25KO mice, we measured serum IL-13 concentration. Our results demonstrated no difference in IL-13 levels with age or between CD25/IL-17/IFN- $\gamma$ TKO and IL-17/IFN- $\gamma$ DKO groups (Figure 6F).

Because we observed delayed and less severe dacryoadenitis when IFN- $\gamma$ was deleted in the CD25KO mice, we sought to investigate whether IFN- $\gamma \mathrm{R}$ expression and TUNEL $^{+}$cells were also decreased in the CD25/IL-17/ IFN- $\gamma$ TKO mice. IFN- $\gamma \mathrm{R}$ immunostaining in $\mathrm{LG}$ at 4 and $8 \mathrm{~W}$ showed very minimal immunoreactivity in glandular tissue in IL-17/IFNY DKO (Figure 5A) while a mild expression was seen in CD25/IL-17/IFN- $\gamma$ TKO mice.

IL-17/IFN- $\gamma$ DKO had similar levels of TUNEL ${ }^{+}$cells to nonimmune $\mathrm{C} 57 \mathrm{BL} / 6$ mice $(53.25 \pm 16.04$ vs. $32 \pm 6.75$
TUNEL $^{+}$cells/20X field, respectively, $P>0.05$, Figure $5 \mathrm{E}$ and F), while CD25/IL-17/IFN- $\gamma$ TKO mice had mild dispersion of $\mathrm{TUNEL}^{+}$cells in the LG at $8 \mathrm{~W}$, although it was still much lower than CD25KO and CD25/IL-17 DKO mice $(215.67 \pm 23.24$ vs. $429 \pm 64.59$ and $1,100 \pm$ 101.85 TUNEL $^{+}$cells/20X field, $P<0.001$ and $P<0.0001$, respectively, Figure 5E and F).

These results confirm that increased IFN- $\gamma \mathrm{R}$ expression in CD25/IL-17 DKO is associated with the increased apoptosis and increased severity of dacryoadenitis in the CD25KO mouse model of SS. Even though CD25/IL-17/ IFN- $\gamma$ TKO mice had increased disease compared to IL$17 /$ IFN- $\gamma$ DKO, it was much less severe than the CD25KO and CD25/IL-17 DKO parental strains, demonstrating that IFN- $\gamma$ has a greater pathogenic role than IL-17A.

\section{Discussion}

Our results showed that deletion of IL-17A in the CD25KO model accelerated onset and severity of dacryoadenitis. This was accompanied by increased $\mathrm{CD}^{+}$and $\mathrm{CD}^{+} \mathrm{T}$ cell infiltration and increased expression of inflammatory cytokines, IFN- $\gamma$ R, Fas-L and TRAIL, lower levels of local and systemic IL-13 and increased LG apoptosis than CD25KO mice. CD25/IFN- $\gamma$ DKO mice had lower activity levels of caspase-3, and -9 and significant lower number of TUNEL ${ }^{+}$cells. Deletion of IFN $-\gamma$ from CD25/IL-17 DKO (generating a CD25/IL-17/IFN- $\gamma$ TKO) had an inverse effect to CD25/IL-17 DKO, preserving glandular tissue and delaying dacryoadenitis severity.

Tear dysfunction (reduced tear production or increased inflammatory tear content) is responsible for some severe forms of dry eye and may be caused in part by cytokines such as IL- 1 that are released by infiltrating cells or stressed glandular epithelial cells. In the present study, IL-1 $\beta$ transcripts in CD25/IL-17 DKO mice at all ages were significantly higher than in $\mathrm{CD} 25 \mathrm{KO}$ mice and paralleled the lymphocytic infiltration in these mice. The proinflammatory and apoptotic effects of IL-1 in the LG have been extensively studied [30,31]. A single injection of IL-1 into the extraorbital LG induced a mild decrease in LG secretion, while inducing a robust, yet reversible (7 to 13 days) inflammatory response that led to destruction of LG acinar epithelial cells [30]. Similar to these studies, the increased IL-1 $\beta$ in LG of CD25/IL-17 DKO may be critical in inducing inflammatory response in these CD25/IL-17 DKO mice.

Interestingly, both IL-1 and TNF- $\alpha$ can upregulate expression of IFN- $\gamma \mathrm{R}$ [32] and IL-1 was significantly increased in the CD25/IL-17 DKO mice. Increased expression of IFN- $\gamma \mathrm{R}$ in CD25/IL-17 DKO may sensitize to the effects of IFN- $\gamma$ that is secreted by T cells and NK cells. Deletion of IFN- $\gamma$ R in the autoimmune MRL/lpr mice prevented apoptosis of the tubular epithelial cells and development and severity of kidney autoimmune disease [33]. 


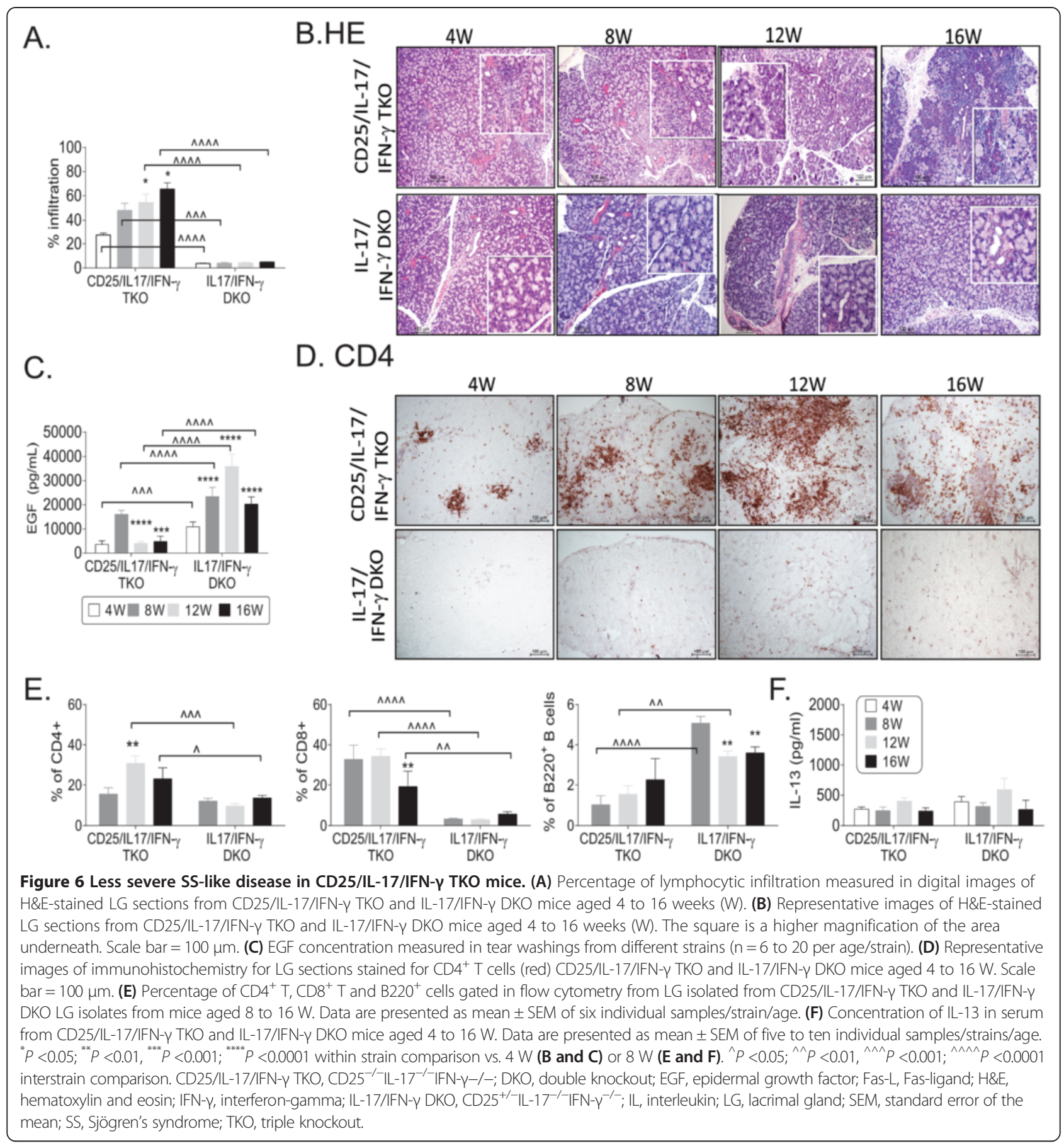

Treatment of colonic cell lines with IFN- $\gamma$ increased the sensitivity of colonic epithelial cells to diverse apoptotic stimuli in concert, via upregulation of caspase-1 [34].

MHC II expression can be induced by IFN- $\gamma$. LG epithelial cells trigger or exacerbate lacrimal autoimmune disease by presentation of autoantigens via MHC II [35]. In our study, higher MHC II transcripts were found in both CD25KO and CD25/IL-17 DKO mice suggesting a greater potential of $\mathrm{MHC} \mathrm{II}^{+}$cells to initiate autoimmunity.
The CD25KO model is a unique system where autoimmunity develops spontaneously in many organs, including salivary gland [6], lacrimal gland [7] and liver [11] and it is age-dependent [36]. IL-17A serum levels [11] and transcripts in LG [7] of CD25KO mice peaked early (around 8 to $12 \mathrm{~W}$ ) suggesting that IL-17A could be participating in early disease development. The number of autoimmune diseases that have been shown to have an IL-17 component has increased after discovery 
of IL-17, including SS [37]. Elevated levels of IL-17A protein were found in minor salivary glands and conjunctiva of SS patients compared to normal control subjects [21,38]. Our group and others showed that neutralization of IL-17A ameliorates corneal barrier disruption in response to desiccating stress $[21,39]$ and decreases expression of matrix metalloproteinase (MMP)-3 and MMP-9 mRNA in the corneal epithelium [21]. Despite the fact that increased IL-17 mRNA and protein has been found in LG of mouse models of SS [7,37,40], the exact role of IL-17 in the LG remains unsolved. Most of the published studies describing a pathogenic role for IL-17A evaluated the salivary gland without description of the LG. Adenovirus-mediated transfer of an IL-17A gene vector to the salivary gland ducts of nonimmune C57BL/6 mice was sufficient to induce an SS-like disease, inclusive of lymphocytic infiltration and decreased salivary flow [41]. Adenovirus-mediated transfer of IL17R:FC decreased sialodenitis in the susceptible C57BL/ 6.NOD-Aec1Aec2 strain [42]. Furthermore, IL-17KO mice that adoptively received Th17 cells from mice immunized with salivary glands extracts had reduced saliva secretion, elevated autoantibody production and pronounced inflammation and tissue damage in the submandibular gland [43]. However, in most of these inducible models, IL-17 response was solely induced without the confounding interaction with other $\mathrm{T}$ cell cytokines, such as IFN- $\gamma$ and IL-13.

The role of IL-17A may also be tissue specific; in dextran sodium sulphate induced-colitis, IL-17 is protective, since neutralization of IL-17 worsened colitis [44] while CD25/IL-17 DKO mice had more severe autoimmune biliary disease [45]. Regarding the LG, genetic deletion of IL$17 \mathrm{~A}$ in an elevated unchecked IFN- $\gamma$ environment in the CD25KO mice did not abolish development of autoimmunity; rather, it accelerated its onset as evidenced by increased LG lymphocytic infiltration and reduced function measured by decreased EGF concentration in tears.

In some experimental models, such as experimental autoimmune uveitis (EAU) both IL-17 and IFN- $\gamma$ seem to be pathologic [46-48]. Our results evaluating the CD25/ IL-17/IFN- $\gamma$ TKO showed that IFN- $\gamma$ is more pathogenic than IL-17A, since deletion of IFN- $\gamma$ in the CD25/IL-17 DKO reversed the acute and severe changes observed in this model, also decreasing IFN- $\gamma \mathrm{R}$ expression and decreasing apoptotic cells. However, because these mice still have a defective IL-2 signaling, disease was not completely abolished. IL-2 is a master regulator of the immune system and it is involved in generation of Tregs, activationinduced cell death and suppression of Th17 generation $[6,10,49]$ and it is critical for Th1 function. Recent studies showed that reduced Treg cell function may contribute to the development of multiorgan systemic autoimmune disease [6]. Spontaneous development of dacryoadenitis and keratoconjunctivitis is observed in mouse strains with defective Treg functions [50,51]. In NOD mice, the deletion of Treg cells worsens autoimmune activity [52]. In an attempt to dissect the individual contributions of lack of Tregs and increased life span of activated $\mathrm{T}$ cells, crossbreeding of CD25KO with B6.lpr mice improved survival and decreased colonic and LG infiltration, demonstrating that some tissue effects are independent of Tregs [10]. We observed increased Fas-L and TRAIL expression in CD25/ IL-17 DKO mice, which have the greatest apoptosis, glandular tissue loss and lymphocytic infiltration compared to parental strains. This is extremely important as increased Fas- $\mathrm{L}$ expression in T cells damages adjacent cells, as demonstrated in CD25/B6.lpr mice and other systems [25-27].

We observed higher EGF concentration levels in IL$17 /$ IFN- $\gamma$ DKO than IL-17KO. It is possible that the LG acini may be very sensitive to low amounts of IFN- $\gamma$ and may account for the differences observed in these two strains. IFN $-\gamma$ has been described to be critical for LG and salivary gland development [53,54]. IFN- $\gamma$ induces apoptosis, death and structural changes to human salivary gland cultures [55,56]. In an in vitro model, mouse conjunctival explant cultures are exquisitely sensitive to IFN- $\gamma$ : minute concentrations of IFN- $\gamma$ at the early days of culture are sufficient to change morphology and induce apoptosis [57]. Our findings describing the CD25/ IL-17/IFN- $\gamma$ TKO demonstrate that IFN- $\gamma$ appears to make a greater contribution to LG inflammation and secretory dysfunction than IL-17, which make actually have some protective functions. We believe that disrupting the balance of $\mathrm{T}$ helper cytokines can alter disease manifestations.

The cross-regulation of IL-13 and IFN- $\gamma$ has been well established in in vitro and in vivo models of asthma $[14,58,59]$ and IL-13 has been shown to be protective to epithelium in vitro $[18,19,23]$. IL-13 can be produced by Th2 cells and also NK cells $[60,61]$. We have also shown that IL-13 is critical for maintenance of conjunctival goblet cell. IL-13KO have lower goblet cell density at baseline and exogenous administration of IL-13 to wild-type mice is capable of rescuing goblet cell after desiccation-induced stress [60]. The conjunctiva, similarly to the airway epithelia, is very susceptible to apoptotic effects of IFN- $\gamma$; IFN$\gamma \mathrm{KO}$ are resistant to desiccation-induced goblet cell loss while exogenous subconjunctival injection of IFN- $\gamma$ in these mice recapitulate the phenotype observed in wild-type mice [62]. In the parental CD25KO strain, there is a spontaneous proliferation of Th1, Th17 and Th2 cells. IL-13 has been shown to be antiapoptotic on colonic and airway epithelial as well as conjunctival fibroblasts $[18,19,23]$. Our results in this manuscript suggest that in a low IL-13 environment in the presence of increased IFN- $\gamma$ and IFN- $\gamma$ R contribute to increased glandular apoptosis. 


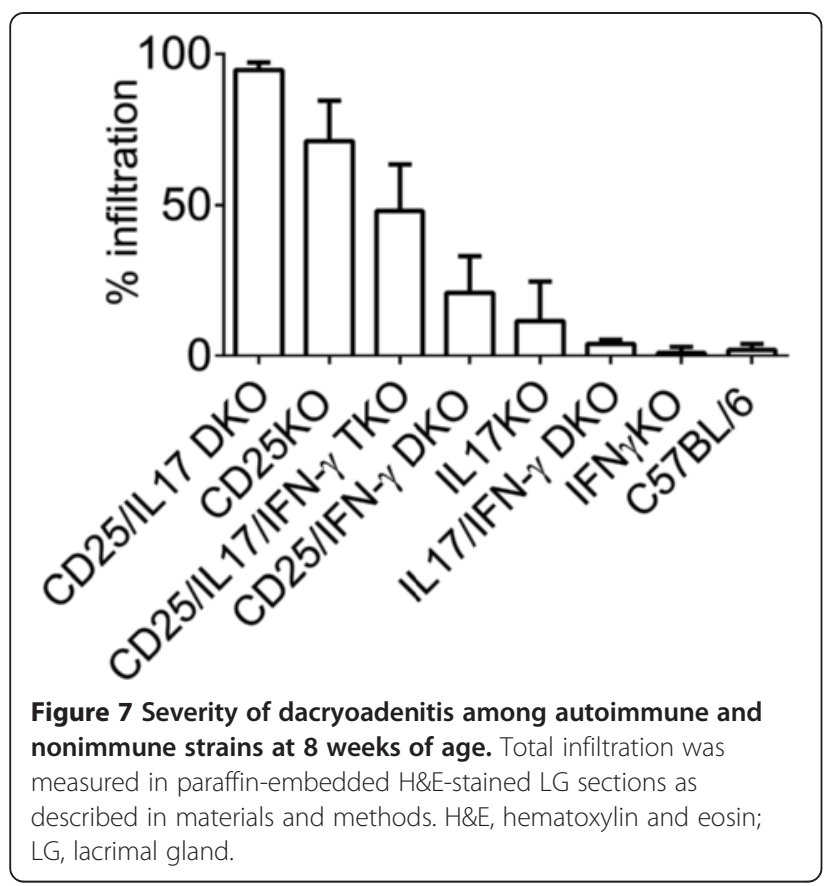

Our results showed lower activity levels of caspases-3 and -9 and lower number of $\mathrm{TUNEL}^{+}$cells in the CD25KO mice compared to the CD25/IL-17DKO and even lower levels in CD25/IFN- $\gamma$ DKO compared to CD25KO mice, demonstrating that IFN- $\gamma$ is critical for the glandular apoptosis. CD25/IFN- $\gamma$ DKO mice had delayed glandular destruction and preserved secretory function at $8 \mathrm{~W}$ [13], in agreement with findings in the NOD model of SS where deletion of IFN- $\gamma$ improved sialodenitis, decreased caspase- 3 activity and TUNEL $^{+}$cells compared to parental NOD strain [12]. We have also shown that in our inducible dry eye model neutralization of IFN$\gamma$ decreased caspase- 3 and caspase- 8 and increased conjunctival goblet density $[24,29]$. Desiccating stress by itself did not increase caspase-9; however, exogenous administration of IFN- $\gamma$ during desiccating stress upregulated caspase-9 RNA [24,29]. These results indicate that IFN- $\gamma$ actively participates in the dacryoadenitis in the CD25KO model through inducing the intrinsic (caspase-9) and common apoptotic (caspase-3) pathways.

We wish to emphasize that this is the first report of using a combination several DKOs and one TKO in an attempt to dissect individual contributions of IL-17A and IFN- $\gamma$ in dacryoadenitis in a murine model. There are certainly some limitations to our study. The disease and LG disarrangement is rather severe and accelerated in the CD25KO mouse, while in humans it may be more insidious and chronic in nature. Although we could not directly prove the involvement of IL-13 in protecting lacrimal epithelium we speculate that an intact Th2 and $\mathrm{B}$ cell response in $\mathrm{CD} 25 \mathrm{KO}$ mice delays development of pathological infiltrates and destruction of parenchymal tissue based on our findings. Additional studies will certainly help dissect the exact contribution of IL-13 in the lacrimal gland immunopathology that develops in the CD25KO mice.

\section{Conclusions}

Taking in consideration what we learned through selective removing genes encoding pathogenic factors in the CD25KO strain, we assembled the graph in Figure 7 that grades severity based on the percentage of total lymphocytic infiltration of the LG at $8 \mathrm{~W}$. A gradient of LG infiltration can be observed, where the CD25/IL-17 DKO has the worst disease, while the CD25/IFN- $\gamma$ DKO [13] is on the other end of the spectrum with much less severe disease. Severity of LG infiltration in the IL-17/IFN$\gamma \mathrm{DKO}$ and IFN- $\gamma \mathrm{KO}$ is similar to that seen in C57BL/6 mice. These results suggest that therapies targeting both cytokines may be more beneficial in the treatment of SS than targeting a single cytokine.

\section{Abbreviations}

${ }^{+}$: Positive; Aec1Aec2: autoimmune exocrinopathy NOD mice in C57BL/6 background; BSA: bovine serum albumin; CD25/IFN- $\mathrm{DKO}: \mathrm{CD}^{2} 5^{-1-} \mathrm{IFN}-\gamma^{-1-}$; CD25/LL-17/IFN- TKO: CD25 $5^{-1}$ IL-17/-IFN- - -/-; CD25KO: CD25 knockout; DKO: double knockout; EAU: experimental autoimmune uveitis; EGF: epidermal growth factor; ELISA: enzyme-linked immunosorbent assay; Fas-L: Fas-ligand; H\&E: hematoxylin and eosin; HPRT-1: hypoxanthine phosphoribosyltransferase 1; IFN- : interferon-gamma; IHC: immunohistochemistry; IgG: immunoglobulin G; IL-17/IFN- - DKO: CD25 $5^{+/} \mid \mathrm{LL}-17^{-1-}$ IFN- $\gamma^{-/-}$; IL: interleukin; KO: knockout; LG: lacrimal gland; MHC-II: major histocompatibility complex class II; MMP: matrix metalloproteinase; NK: natural killer cells; NOD: nonobese diabetic; PBS: phosphate-buffered saline; R: receptor; SS: Sjögren's syndrome; Th: T helper; TKO: triple knockout; TNF: tumor necrosis factor; TRAIL: TNF-related apoptosisinducing ligand; Treg: T regulatory cells; TUNEL: terminal deoxynucleotidyl transferase dUTP nick end labeling; W: week.

\section{Competing interests}

The authors declare that they have no competing interests.

\section{Authors' contributions}

All authors contributed the final manuscript. FB, FLB, FSAP, SCP, and CSDP participated in the design of the study, statistical analysis and interpretation of the data, drafting the article and critical revision of the article for important intellectual content. RMC, FB, FLB, FSAP, RMC, EAV and CSDP assisted with collection and acquisition of the data and critically revised the manuscript. All authors have read and approved the manuscript for publication.

\section{Acknowledgments}

This work was supported by Biology of Inflammation Pilot Grant/BCM (CSDP), NIH EY-002520-36 (Core Grant for Vision Research Department of Ophthalmology); Research to Prevent Blindness; Oshman Foundation; William Stamps Farish Fund, Hamill Foundation and by the Cytometry and Cell Sorting Core at Baylor College of Medicine, which is funded by the NIH NIAID P30AI036211, NCI P30CA125123, and NCRR S10RR024574. We thank Joel Sederstrom who provided expert guidance with flow cytometry experiments and Mahira Zaheer and Kevin Tesareski for technical assistance. Part of this manuscript was presented as an abstract in the $28^{\text {th }}$ Biennial Cornea Conference, Boston, October 18-20, 2013.

Received: 24 November 2014 Accepted: 24 February 2015

Published online: 10 March 2015 


\section{References}

1. Stern ME, Gao J, Schwalb TA, Ngo M, Tieu DD, Chan CC, et al. Conjunctival T-cell subpopulations in Sjogren's and non-Sjogren's patients with dry eye. Invest Ophthalmol Vis Sci. 2002;43:2609-14.

2. Zoukhri D, Hodges RR, Byon D, Kublin CL. Role of proinflammatory cytokines in the impaired lacrimation associated with autoimmune xerophthalmia. Invest Ophthalmol Vis Sci. 2002:43:1429-36.

3. Naito Y, Matsumoto I, Wakamatsu E, Goto D, Sugiyama T, Matsumura R, et al. Muscarinic acetylcholine receptor autoantibodies in patients with Sjogren's syndrome. Ann Rheum Dis. 2005;64:510-1.

4. Bacman S, Sterin-Borda L, Camusso JJ, Arana R, Hubscher O, Borda E. Circulating antibodies against rat parotid gland M3 muscarinic receptors in primary Sjogren's syndrome. Clin Exp Immunol. 1996;104:454-9.

5. Bacman S, Perez LC, Sterin-Borda L, Hubscher O, Arana R, Borda E. Autoantibodies against lacrimal gland M3 muscarinic acetylcholine receptors in patients with primary Sjogren's syndrome. Invest Ophthalmol Vis Sci. 1998;39:151-6.

6. Sharma R, Zheng L, Guo X, Fu SM, Ju ST, Jarjour WN. Novel animal models for Sjogren's syndrome: expression and transfer of salivary gland dysfunction from regulatory T cell-deficient mice. J Autoimmun. 2006;27:289-96.

7. Rahimy E, Pitcher III JD, Pangelinan SB, Chen W, Farley WJ, Niederkorn JY et al. Spontaneous autoimmune dacryoadenitis in aged CD25KO mice. Am J Pathol. 2010;177:744-53.

8. Sadlack B, Lohler J, Schorle H, Klebb G, Haber H, Sickel E, et al. Generalized autoimmune disease in interleukin-2-deficient mice is triggered by an uncontrolled activation and proliferation of CD4+ T cells. Eur J Immunol. 1995;25:3053-9.

9. Sadlack B, Merz H, Schorle H, Schimpl A, Feller AC, Horak I. Ulcerative colitis-like disease in mice with a disrupted interleukin-2 gene. Cell. 1993;75:253-61.

10. Sharma R, Bagavant H, Jarjour WN, Sung SS, Ju ST. The role of Fas in the immune system biology of IL-2R alpha knockout mice: interplay among regulatory $T$ cells, inflammation, hemopoiesis, and apoptosis. J Immunol. 2005:175:1965-73.

11. de Paiva CS, Hwang CS, Pitcher III JD, Pangelinan SB, Rahimy E, Chen W, et al. Age-related T-cell cytokine profile parallels corneal disease severity in Sjogren's syndrome-like keratoconjunctivitis sicca in CD25KO mice. Rheumatology (Oxford). 2010;49:246-58.

12. Lan RY, Salunga TL, Tsuneyama K, Lian ZX, Yang GX, Hsu W, et al. Hepatic IL-17 responses in human and murine primary biliary cirrhosis. J Autoimmun. 2009;32:43-51.

13. Cha S, Brayer J, Gao J, Brown V, Killedar S, Yasunari U, et al. A dual role for interferon-gamma in the pathogenesis of Sjogren's syndrome-like autoimmune exocrinopathy in the nonobese diabetic mouse. Scand J Immunol. 2004;60:552-65.

14. Pelegrino FS, Volpe EA, Gandhi NB, Li DQ, Pflugfelder SC, de Paiva CS. Deletion of interferon-gamma delays onset and severity of dacryoadenitis in CD25KO mice. Arthritis Res Ther. 2012;14:R234

15. Ford JG, Rennick D, Donaldson DD, Venkayya R, McArthur C, Hansell E, et al. II-13 and IFN-gamma: interactions in lung inflammation. J Immunol. 2001:167:1769-77.

16. Shahzeidi S, Aujla PK, Nickola TJ, Chen Y, Alimam MZ, Rose MC. Temporal analysis of goblet cells and mucin gene expression in murine models of allergic asthma. Exp Lung Res. 2003;29:549-65.

17. Tran MT, Tellaetxe-Isusi M, Elner V, Strieter RM, Laush RN, Oaks JE. Proinflammatory cytokines induce RANTES and MCP-1 synthesis in human corneal keratocytes but not in corneal epithelial cells. B-chemokine synthesis in corneal cells. Invest Ophthalmol Vis Sci. 1996;37:987-96.

18. Kondo M, Tamaoki J, Takeyama K, Isono K, Kawatani K, Izumo T, et al. Elimination of IL-13 reverses established goblet cell metaplasia into ciliated epithelia in airway epithelial cell culture. Allergol Int. 2006;55:329-36.

19. Singhera GK, Macredmond R, Dorscheid DR. Interleukin-9 and -13 inhibit spontaneous and corticosteroid induced apoptosis of normal airway epithelial cells. Exp Lung Res. 2008;34:579-98.

20. Wright K, Kolios G, Westwick J, Ward SG. Cytokine-induced apoptosis in epithelial HT-29 cells is independent of nitric oxide formation. Evidence for an interleukin-13-driven phosphatidylinositol 3-kinase-dependent survival mechanism. J Biol Chem. 1999:274:17193-201.

21. Iwakura $Y$, Ishigame $H$. The IL-23/IL-17 axis in inflammation. J Clin Invest. 2006:116:1218-22

22. de Paiva CS, Chotikavanich S, Pangelinan SB, Pitcher Jl, Fang B, Zheng X, et al. IL-17 disrupts corneal barrier following desiccating stress. Mucosal Immunol. 2009;2:243-53.
23. Strong B, Farley W, Stern ME, Pflugfelder SC. Topical cyclosporine inhibits conjunctival epithelial apoptosis in experimental murine keratoconjunctivitis sicca. Cornea. 2005;24:80-5

24. Fujitsu Y, Fukuda K, Kimura K, Seki K, Kumagai N, Nishida T. Protection of human conjunctival fibroblasts from NO-induced apoptosis by interleukin-4 or interleukin-13. Invest Ophthalmol Vis Sci. 2005;46:797-802.

25. Zhang X, Chen W, de Paiva CS, Corrales RM, Volpe EA, McClellan AJ, et al. Interferon-gamma exacerbates dry eye-induced apoptosis in conjunctiva through dual apoptotic pathways. Invest Ophthalmol Vis Sci. 2011;52:6279-85.

26. Xiao S, Sung SS, Fu SM, Ju ST. Combining Fas mutation with interleukin-2 deficiency prevents colitis and lupus: implicating interleukin-2 for autoreactive $T$ cell expansion and Fas ligand for colon epithelial cell death. J Biol Chem. 2003;278:52730-8.

27. D'Souza SD, Bonetti B, Balasingam V, Cashman NR, Barker PA, Troutt AB, et al. Multiple sclerosis: Fas signaling in oligodendrocyte cell death. J Exp Med. 1996;184:2361-70.

28. Stassi G, De MR, Trucco G, Rudert W, Testi R, Galluzzo A, et al. Nitric oxide primes pancreatic beta cells for Fas-mediated destruction in insulindependent diabetes mellitus. J Exp Med. 1997;186:1193-200.

29. Zhang X, Chen W, de Paiva CS, Volpe EA, Gandhi NB, Farley WJ, et al. Desiccating stress induces CD4(+) T-cell-mediated Sjogren's syndrome-like corneal epithelial apoptosis via activation of the extrinsic apoptotic pathway by interferon-gamma. Am J Pathol. 2011;179:1807-14.

30. Zhang X, de Paiva CS, Su Z, Volpe EA, Li DQ, Pflugfelder SC. Topical interferon-gamma neutralization prevents conjunctival goblet cell loss in experimental murine dry eye. Exp Eye Res. 2014;118:117-24.

31. Zoukhri D, Macari E, Kublin CL. A single injection of interleukin-1 induces reversible aqueous-tear deficiency, lacrimal gland inflammation, and acinar and ductal cell proliferation. Exp Eye Res. 2007;84:894-904.

32. Zoukhri D, Ko S, Stark PC, Kublin CL. Roles of caspase 1 and extracellular signal-regulated kinase in inflammation-induced inhibition of lacrimal gland protein secretion. Invest Ophthalmol Vis Sci. 2008:49:4392-8.

33. Shirey KA, Jung JY, Maeder GS, Carlin JM. Upregulation of IFN-gamma receptor expression by proinflammatory cytokines influences IDO activation in epithelial cells. J Interferon Cytokine Res. 2006;26:53-62.

34. Schwarting A, Wada T, Kinoshita K, Tesch G, Kelley VR. IFN-gamma receptor signaling is essential for the initiation, acceleration, and destruction of autoimmune kidney disease in MRL-Fas(lpr) mice. J Immunol. 1998;161:494-503

35. O'Connell J, Bennett MW, Nally K, O'Sullivan GC, Collins JK, Shanahan F. Interferon-gamma sensitizes colonic epithelial cell lines to physiological and therapeutic inducers of colonocyte apoptosis. J Cell Physiol. 2000;185:331-8.

36. Guo Z, Song D, Azzarolo AM, Schechter JE, Warren DW, Wood RL, et al. Autologous lacrimal-lymphoid mixed-cell reactions induce dacryoadenitis in rabbits. Exp Eye Res. 2000;71:23-31.

37. Nguyen $C Q, H u M H, L i$ Y, Stewart C, Peck AB. Salivary gland tissue expression of interleukin-23 and interleukin-17 in Sjogren's syndrome: findings in humans and mice. Arthritis Rheum. 2008;58:734-43.

38. Katsifis GE, Rekka S, Moutsopoulos NM, Pillemer S, Wahl SM. Systemic and local interleukin-17 and linked cytokines associated with Sjogren's syndrome immunopathogenesis. Am J Pathol. 2009:175:1167-77.

39. Chauhan SK, El AJ, Ecoiffier T, Goyal S, Zhang Q, Saban DR, et al. Autoimmunity in dry eye is due to resistance of Th17 to Treg suppression. J Immunol. 2009;182:1247-52.

40. Jie G, Jiang $Q$, Rui Z, Yifei Y. Expression of interleukin-17 in autoimmune dacryoadenitis in MRL/Ipr mice. Curr Eye Res. 2010;35:865-71.

41. Nguyen $C Q$, Yin $H$, Lee BH, Carcamo WC, Chiorini JA, Peck AB. Pathogenic effect of interleukin-17A in induction of Sjogren's syndrome-like disease using adenovirus-mediated gene transfer. Arthritis Res Ther. 2010;12:R220.

42. Nguyen $\mathrm{CQ}$, Yin $\mathrm{H}$, Lee $\mathrm{BH}$, Chiorini JA, Peck AB. IL17: potential therapeutic target in Sjogren's syndrome using adenovirus-mediated gene transfer. Lab Invest. 2011;91:54-62.

43. Lin X, Rui K, Deng J, Tian J, Wang X, Wang S, et al. Th17 cells play a critical role in the development of experimental Sjogren's syndrome. Ann Rheum Dis 2014. doi:10.1136/annrheumdis-2013-204584.

44. Ogawa A, Andoh A, Araki Y, Bamba T, Fujiyama Y. Neutralization of interleukin-17 aggravates dextran sulfate sodium-induced colitis in mice. Clin Immunol. 2004;110:55-62.

45. Yang $W$, Yao Y, Yang YQ, Lu FT, Li L, Wang YH, et al. Differential modulation by IL-17A of cholangitis versus colitis in IL-2Ralpha deleted mice. PLoS One. 2014;9:e105351. 
46. Luger D, Silver PB, Tang J, Cua D, Chen Z, Iwakura Y, et al. Either a Th17 or a Th1 effector response can drive autoimmunity: conditions of disease induction affect dominant effector category. J Exp Med. 2008;205:799-810.

47. Billiau A, Heremans $H$, Vandekerckhove F, Dijkmans R, Sobis H, Meulepas E, et al. Enhancement of experimental allergic encephalomyelitis in mice by antibodies against IFN-gamma. J Immunol. 1988;140:1506-10.

48. Caspi RR, Chan CC, Grubbs BG, Silver PB, Wiggert B, Parsa CF, et al. Endogenous systemic IFN-gamma has a protective role against ocular autoimmunity in mice. J Immunol. 1994;152:890-9.

49. Willerford DM, Chen J, Ferry JA, Davidson L, Ma A, Alt FW. Interleukin-2 receptor alpha chain regulates the size and content of the peripheral lymphoid compartment. Immunity. 1995;3:521-30.

50. Shull MM, Ormsby I, Kier AB, Pawlowski S, Diebold RJ, Yin M, et al. Targeted disruption of the mouse-transforming growth factor-beta 1 gene results in multifocal inflammatory disease. Nature. 1992;359:693-9.

51. McCartney-Francis NL, Mizel DE, Frazier-Jessen M, Kulkarni AB, McCarthy JB, Wahl SM. Lacrimal gland inflammation is responsible for ocular pathology in TGF-beta 1 null mice. Am J Pathol. 1997;151:1281-8.

52. Nakahara M, Nagayama Y, Ichikawa T, Yu L, Eisenbarth GS, Abiru N. The effect of regulatory T-cell depletion on the spectrum of organ-specific autoimmune diseases in nonobese diabetic mice at different ages. Autoimmunity. 2011:44:504-10.

53. Daniels PJ, McArthur CP, Heruth DP, Rothberg PG, Pasztor L, Wang Y Cytokine-mediated stimulation of laminin expression and cell-growth arrest in a human submandibular gland duct-cell line (HSG). Arch Oral Biol. 1999:44:603-15.

54. Daniels PJ, Gustafson SA, French D, Wang Y, DePond W, McArthur CP. Interferon-mediated block in cell cycle and altered integrin expression in a differentiated salivary gland cell line (HSG) cultured on Matrigel. J Interferon Cytokine Res. 2000;20:1101-9.

55. Wu AJ, Chen ZJ, Tsokos M, O'Connell BC, Ambudkar IS, Baum BJ. Interferongamma induced cell death in a cultured human salivary gland cell line. J Cell Physiol. 1996;167:297-304.

56. Kamachi M, Kawakami A, Yamasaki S, Hida A, Nakashima T, Nakamura H, et al. Regulation of apoptotic cell death by cytokines in a human salivary gland cell line: distinct and synergistic mechanisms in apoptosis induced by tumor necrosis factor alpha and interferon gamma. J Lab Clin Med. 2002;139:13-9.

57. Coursey TG, Tukler Henriksson J, Chen M, Pflugfelder SC. IFN-\{gamma\} influences the proliferation and differentiation of conjunctival goblet cells. ARVO Meeting Abstracts. 2014;55:2774.

58. Irifune K, Yokoyama A, Sakai K, Watanabe A, Katayama H, Ohnishi H, et al. Adoptive transfer of T-helper cell type 1 clones attenuates an asthmatic phenotype in mice. Eur Respir J. 2005:25:653-9.

59. Heller NM, Matsukura S, Georas SN, Boothby MR, Rothman PB, Stellato C, et al. Interferon-gamma inhibits STAT6 signal transduction and gene expression in human airway epithelial cells. Am J Respir Cell Mol Biol. 2004;31:573-82.

60. de Paiva CS, Raince JK, McClellan AJ, Shanmugam KP, Pangelinan SB Volpe EA, et al. Homeostatic control of conjunctival mucosal goblet cells by NKT-derived IL-13. Mucosal Immunol. 2011:4:397-408.

61. Hoshino T, Winkler-Pickett RT, Mason AT, Ortaldo JR, Young HA. IL-13 production by NK cells: IL-13-producing NK and T cells are present in vivo in the absence of IFN-gamma. J Immunol. 1999;162:51-9.

62. de Paiva CS, Villarreal AL, Corrales RM, Rahman HT, Chang VY, Farley WJ, et al. Dry Eye-induced conjunctival epithelial squamous metaplasia is modulated by interferon-\{gamma\}. Invest Ophthalmol Vis Sci. 2007:48:2553-60.

\section{Submit your next manuscript to BioMed Central and take full advantage of:}

- Convenient online submission

- Thorough peer review

- No space constraints or color figure charges

- Immediate publication on acceptance

- Inclusion in PubMed, CAS, Scopus and Google Scholar

- Research which is freely available for redistribution

Submit your manuscript at www.biomedcentral.com/submit 